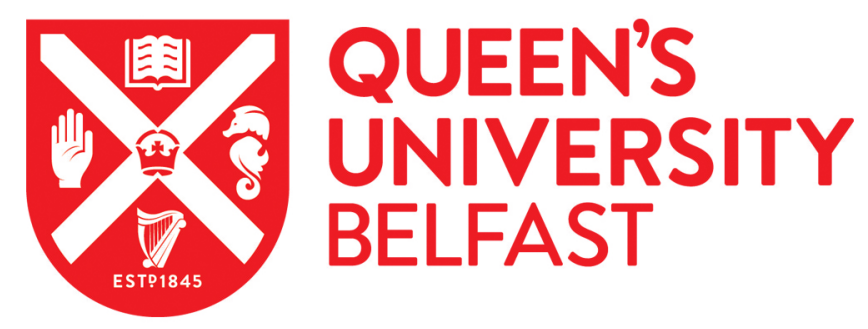

\title{
Iron Age Pastoral Nomadism and Agriculture in the Eastern Eurasian Steppe: Implications from Dental Palaeopathology and Stable Carbon and Nitrogen Isotopes
}

Murphy, E. M., Beer, N., Schulting, R., Chistov, Y., Kasparov, A., \& Pshenitsyna, M. (2013). Iron Age Pastoral Nomadism and Agriculture in the Eastern Eurasian Steppe: Implications from Dental Palaeopathology and Stable Carbon and Nitrogen Isotopes. Journal of Archaeological Science, 40(5), 2547-2560.

https://doi.org/10.1016/j.jas.2012.09.038

\section{Published in:}

Journal of Archaeological Science

\section{Document Version:}

Peer reviewed version

Queen's University Belfast - Research Portal:

Link to publication record in Queen's University Belfast Research Portal

\begin{abstract}
Publisher rights
This is the author's version of a work that was accepted for publication in Journal of Archaeological Science. Changes resulting from the publishing process, such as peer review, editing, corrections, structural formatting, and other quality control mechanisms may not be reflected in this document. Changes may have been made to this work since it was submitted for publication. A definitive version was subsequently published in Journal of Archaeological Science, [VOL 40, ISSUE 5, 2013]
\end{abstract}

\section{General rights}

Copyright for the publications made accessible via the Queen's University Belfast Research Portal is retained by the author(s) and / or other copyright owners and it is a condition of accessing these publications that users recognise and abide by the legal requirements associated with these rights.

\section{Take down policy}

The Research Portal is Queen's institutional repository that provides access to Queen's research output. Every effort has been made to ensure that content in the Research Portal does not infringe any person's rights, or applicable UK laws. If you discover content in the Research Portal that you believe breaches copyright or violates any law, please contact openaccess@qub.ac.uk. 


\section{Accepted Manuscript}

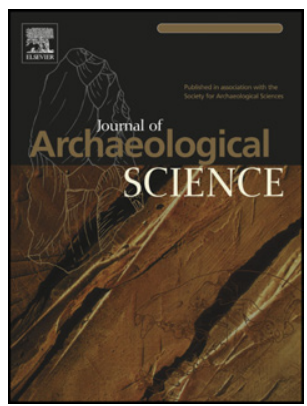

Iron Age Pastoral Nomadism and Agriculture in the Eastern Eurasian Steppe:

Implications from Dental Palaeopathology and Stable Carbon and Nitrogen Isotopes

Eileen M. Murphy, Rick Schulting, Nick Beer, Yuri Chistov, Alexey Kasparov, Margarita Pshenitsyna

PII:

S0305-4403(12)00454-2

DOI:

10.1016/j.jas.2012.09.038

Reference: $\quad$ YJASC 3455

To appear in: Journal of Archaeological Science

Received Date: 24 June 2012

Accepted Date: 25 September 2012

Please cite this article as: Murphy, E.M., Schulting, R., Beer, N., Chistov, Y., Kasparov, A., Pshenitsyna, M., Iron Age Pastoral Nomadism and Agriculture in the Eastern Eurasian Steppe: Implications from Dental Palaeopathology and Stable Carbon and Nitrogen Isotopes, Journal of Archaeological Science (2012), doi: 10.1016/j.jas.2012.09.038.

This is a PDF file of an unedited manuscript that has been accepted for publication. As a service to our customers we are providing this early version of the manuscript. The manuscript will undergo copyediting, typesetting, and review of the resulting proof before it is published in its final form. Please note that during the production process errors may be discovered which could affect the content, and all legal disclaimers that apply to the journal pertain. 
Iron Age Pastoral Nomadism and Agriculture in the Eastern Eurasian Steppe: Implications from Dental Palaeopathology and Stable Carbon and Nitrogen Isotopes

Eileen M. Murphy ${ }^{1}$, Rick Schulting ${ }^{2}$, Nick Beer ${ }^{3}$, Yuri Chistov ${ }^{4}$, Alexey Kasparov ${ }^{5}$, Margarita Pshenitsyna $^{6}$

1 \& 3. School of Geography, Archaeology and Palaeoecology, Queen's University Belfast, Belfast BT7 1NN, Northern Ireland.

2. School of Archaeology, University of Oxford, Oxford OX1 2PG, England.

4. Peter the Great Museum of Anthropology and Ethnography (Kunstkamera), 3 University Embankment, St. Petersburg 199034, Russia.

5 \& 6. Institute for the History of Material Culture, 18 Dvortsovaya Embankment, St Petersburg 191186, Russia.

* Corresponding author. Tel.: +44 7801545674.

E-mail address: eileen.murphy@qub.ac.uk (E. M. Murphy)

\section{Highlights}

- We examine the diet of two Iron Age populations from the eastern Eurasian steppe.

- The proxies used are dental palaeopathology and stable carbon and nitrogen isotopes.

- These populations did not solely rely on their herds for subsistence.

- Millet and fish formed a substantial component of their diet.

- The subsistence strategies of steppe mobile pastoralists are highly complex.

Keywords southern Siberia; Scythian; millet; fish; caries; calculus

\section{Abstract}

Iron Age societies of the eastern Eurasian steppe are traditionally viewed as nomadic pastoralists. However, recent archaeological and anthropological research in Kazakhstan has reminded us that pastoralist economies can be highly complex and involve agriculture. This paper explores the nature of the pastoralist economies in two Early Iron Age populations from the burial grounds of Ai-Dai and Aymyrlyg in Southern Siberia. These populations represent two cultural groups of the Scythian World - the Tagar Culture of the Minusinsk Basin and the Uyuk Culture of Tuva. Analysis of dental palaeopathology and 
carbon and nitrogen stable isotopes suggests that domesticated cereals, particularly millet, and fish formed a major component of the diet of both groups. The findings contribute to the emerging picture of the nuances of Early Iron Age subsistence strategies on the eastern steppe.

\section{Introduction}

The Iron Age societies of the Eurasian steppe are generally referred to as nomadic pastoralists (e.g. Gryaznov, 1969: 131; Vainshstein, 1980: 51; Koryakova and Epimakhov, 2006: 203). This form of economy largely revolves around the structured migratory management of domestic herd animals (Khazanov, 1984: 17; Cribb, 1991: 20; Barfield, 1993: 4; Salzman, 2002: 245) and it is used to enable an efficient exploitation of seasonal pastures (Crawford and Leonard, 2002: 3). The relationship between pastoral nomadism and agriculture in the Iron Age societies of the Eurasian steppe has been generally poorly understood and there has been a tendency to over-simplify the situation. Recent anthropological and archaeological research, however, has demonstrated that pastoral systems are highly variable and complex, operating at a community-level and being determined 'according to the opportunities and risks presented by social, political, and economic interaction among pastoralists and their neighbors' (Frachetti, 2008: 16-17; see also Crawford and Leonard, 2002: 2; Koryakova and Epimakhov, 2006: 204-209).

The adoption of pastoralism across the Eurasian steppe does not appear to have been a uniform process - in the west it is believed to have emerged from Neolithic agricultural societies, whereas in the east it appears to have developed from the mobile hunting-fishing economy of the Eneolithic (c. 3500 BC) (Frachetti, 2008: 20-21; 2012: 5). Theories proposed to account for the development of pastoral nomadism in the eastern steppe include climate change, overpopulation, a natural evolution from advanced pastoralism and simply as a mechanism for increased economic profitability (Di Cosmo, 2002: 33-34). Kohl $(2007: 157,162)$ observes that, paradoxically, agriculture appears to have become well established in the western steppe during the Iron Age - at the very time when true mounted pastoral nomadism also emerged. He envisaged a clear difference between those who practiced pastoralism supplemented by cultivation and those who were mounted pastoralist nomads. Di Cosmo (1994: 1094) undertook a detailed review of the evidence for the economic basis of the nomads of the eastern steppe and concluded that various forms 
of plant-based agriculture were undertaken as a supplementary activity by these groups from the Neolithic onwards.

This paper examines the diet and subsistence practices of two Early Iron Age cemetery populations from southern Siberia - Ai-Dai in the Minusinsk Basin and Aymyrlyg in Tuva - through dental palaeopathology and stable carbon and nitrogen isotope analysis. As well as comparing two sites, the study involves comparison of two cultural groups of the Scythian World - the Tagar Culture of the Minusinsk Basin and the Uyuk Culture of Tuva (Fig. 1). As such, this approach not only provides new scientific information at a regional, cultural level but it also contributes to the emerging picture concerning the nuances of Early Iron Age subsistence strategies in the eastern steppe (see Hanks, 2010: 479; Frachetti, 2012; Svyatko et al., submitted).

\section{Archaeological Context}

\subsection{The cemeteries}

Ai-Dai is located on the west bank of the Yenisey River, near the town of Sayanogorsk,

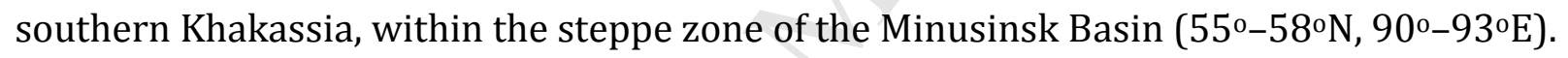
The climate is very continental, with an absolute temperature range of $+39^{\circ} \mathrm{C}$ to $-53^{\circ} \mathrm{C}$. Modern rainfall averages $250 \mathrm{~mm}$ per annum and falls mainly in the summer months (Nicholson 2011: 365). The Ai-Dai cemetery complex was excavated during the 1990s in advance of construction work (Nikolaev, 1997; Pshenitsyna, 1997). The site contained some 40 Iron Age burial mounds, or kurgans, believed to date to the transition between the Podgornovo ( $8^{\text {th }}-6^{\text {th }}$ centuries BC) and Saragash (6 $6^{\text {th }}-3^{\text {rd }}$ centuries BC) phases of the Tagar Culture (Pshenitsyna, 1997: 34; Bokovenko, 2006: 863; but see Kuzmin, 2008 and Svyatko et al., 2009 for more recent discussions). A radiocarbon date of $2440 \pm 16$ yrs BP (UB-4957) from a structural timber recovered from Timber Chamber 2 of Kurgan 4 at AiDai III appears to broadly support this chronological assignation. Unfortunately this part of the calibration curve features a well-known plateau (Michczynski, 2004; van der Plicht, 2004), thus providing only a broad estimate of 740-410 BC at 95\% confidence (CALIB 6.0). The burials comprise a subterranean rectangular timber chamber beneath a stone fence construction, typical of this period. They each contained between three and 20 individuals including males, females and juveniles. Personal objects and/or funerary offerings included weaponry, pottery, toiletry items and gold objects (Pshenitsyna, 1997: 33-34). 
The substantial cemetery complex of Aymyrlyg is located in the Ulug-Khemski region of the Autonomous Republic of Tuva. It is situated near the Sayansky ravine of the Yenisey River, on the left bank of the Chaa-Hol River, where it extends for over $10 \mathrm{~km}$ and is considered to be the largest archaeological monument located within the flooding zone of the SayanoShushenskoye hydro-electric power station (Mandelshtam, 1983: 25). The climate in modern Tuva is even more continental than in the Minusinsk Basin and the temperature can drop as low as $-58^{\circ} \mathrm{C}$ (Nicholson 2011: 365). Mean winter temperatures lie between $25^{\circ} \mathrm{C}$ and $-34^{\circ} \mathrm{C}$, with a mean summer temperature of $19^{\circ} \mathrm{C}$ or $20^{\circ} \mathrm{C}$ which can sometimes rise as high as $35^{\circ} \mathrm{C}$ to $40^{\circ} \mathrm{C}$. The annual precipitation is very low and ranges from 100 to $300 \mathrm{~mm}$ (Gracheva 2004: 247).

Although some of the Scythian-period burials recovered from Aymyrlyg are considered to date to the earlier phases of the Uyuk Culture in the 7 th -6 th centuries BC, the majority of burials are thought to derive from the Late phase of this culture, approximately the 5th 2nd centuries BC (Mandelshtam, 1992: 183, 185). The exterior of each tomb generally comprised a low, rectangular-shaped wall made up of stone slabs sunk edgewise into the ground. The most frequently encountered subterranean structures were rectangular timber chambers, containing as many as 15 individuals (Fig. 2). A wide variety of grave goods were recovered, including weaponry, horse accoutrements, utilitarian tools, pottery and wooden vessels, foodstuffs, items of clothing, jewellery, personal items and possible ritual objects (Mandelshtam, 1983; 1992).

\subsection{Previous understanding of Tagar and Uyuk economies}

Previous archaeological work has acknowledged the mixed nature of subsistence strategies for both the Tagar and Uyuk Cultures but there is a general lack of clarity concerning these practices. In his ethnographic study of pastoral nomadism in Tuva, Vainshtein (1980: 51) concluded that the early Iron Age economy was based upon a semi-nomadic form of pastoralism, combined with cereal cultivation, hunting and gathering. Mandelshtam (1992: 193) was of the opinion, however, that, while members of the Uyuk Culture may have practiced occasional agriculture, it was more likely that agricultural products were obtained through exchange processes with neighbouring farming tribes. With regard to the Tagar Culture, it has been suggested they practiced semi-nomadic pastoral stock-rearing and a primitive form of agriculture based upon farming millet (Okladnikov, 1959: 34; Gryaznov, 1969: 213; Zavitukhina, 1978: 80; Di Cosmo 1994: 1104). More recently, it was 
stated that, while the economy focused on sheep pastoralism, the discovery of large numbers of bronze sickles is indicative of the exploitation of wild cereals (Bokovenko, 2006: 877). The Tagar Culture has also been described, however, as 'one of the most pure nomadic cultures', in relation to its emphasis on stock-breeding, in the Scythian World (van Geel et al., 2004: 1739).

The remains of domesticated animals generally predominate in burial and settlement contexts, which might be seen as supporting pastoralism (Mannai-Ool, 1970: 91; Vainshtein, 1980: 52; Ermolova, 1983: 106; Vadetskaya, 1986: 102-128). The distribution of large tribal burial grounds has been interpreted as evidence that both cultures engaged in cyclic migration with fixed routes and set winter camp sites, similar to the seasonal strategies identified in more recent ethnographic studies (Vainshtein, 1980: 96; Mandelshtam, 1992: 193; Bokovenko, 1995: 255). While less well represented, remains associated with hunting and fishing have also been recovered (Vadetskaya, 1986: 102-128; Mandelshtam, 1992: 193).

Although generally rare, the remains of millet, barley and tools utilized for plant processing have been recovered from both Tagar and Uyuk burials (Vadetskaya, 1986: 94, 105 and 118; Mandelshtam, 1992: 193; Di Cosmo, 1994: 1104). Irrigation systems are believed to be associated with both cultures and have been interpreted as a further indicator of land cultivation (Oklandnikov, 1959: 34; Zavitukhina, 1978: 80; Vainshtein, 1980: 145). In addition, it would appear that semi-permanent settlement was present in the Minusinsk Basin at this time (Okladnikov, 1959: 34; Gryaznov, 1969: 216; Vadetskaya, 1986: 94). The extent to which this is necessarily linked with agriculture, however, can be questioned (see Anthony et al., 2005: 409).

The preceding review would tend to suggest that the Uyuk and Tagar Cultures did indeed practice a complex form of pastoralism which included an element of hunting and fishing. The archaeological and later ethnographic evidence also suggests that these groups practiced cultivation, though its extent and importance in the diet is unknown. The use of dental palaeopathology and carbon and nitrogen stable isotopes in the current study will attempt to refine these interpretations, at least with respect to the populations buried at Ai-Dai and Aymyrlyg. 


\section{Methodology}

\subsection{Dental palaeopathology}

The link between the diet of past populations and dental palaeopathological lesions is well established (Hillson, 2000: 249) and numerous studies have been undertaken which address temporal and chronological dietary and subsistence-related questions (e.g. Turner, 1979; Pechenkina et al., 2002; Keenleyside, 2008) as well as focus on age, sex and statusrelated differences (e.g. Lukacs, 1996; Cucina and Tiesler, 2003). Studies of past subsistence strategies have tended to focus on dental lesions in hunter-gatherer or agricultural populations or examined the impact on dental health of the transition to agriculture (e.g. Larsen, 1995). Only a handful of studies involving dental palaeopathological analysis have been undertaken on Eurasian pastoralist populations (e.g. Eng, 2007; Murphy, forthcoming), and the impact of diet on the dental health of these groups is generally poorly understood.

The dental lesions analysed here comprise caries, abscesses, ante-mortem tooth loss (AMTL), periodontal disease and calculus formation. A complex interaction exists between these various dental diseases, some of which may be primary and others a secondary response (Lukacs, 1989: fig. 1). Previous studies have indicated that, although there can be a variety of aetiologies for the lesions, when studied at population level caries and calculus formation are particularly useful for palaeodietary reconstruction (e.g. Lillie, 1996; Keenleyside, 2008). Dental caries involves the localized demineralization of dental hard tissues by organic acids that arise as a consequence of the bacterial fermentation of dietary carbohydrates and is exacerbated by the consumption of soft, sticky foods (Larsen, 1997, 65). A global study by Turner (1979: table 3) revealed a general increase - albeit with considerable variability - in the prevalence of caries from hunter-gatherers $(1.7 \%)$ to mixed foraging/agriculture (4.4\%) to agriculture (8.6\%). Clinical studies have revealed that dietary proteins and fats are generally non-cariogenic, and can have a protective effect against their development (Rugg-Gunn, 1993: 253). Studies of pre-contact Greenland populations, who consumed an almost entirely animal-based diet and practically no carbohydrates, for example, were found to have extremely low rates of caries (Pedersen, 1947: 729).

Dental calculus forms as a consequence of the mineralization of the bacterial plaque which is attached to the surface of a tooth (Hillson, 1996: 255). The precise nature of the 
relationship between diet and calculus formation is not fully understood and high levels of calculus have been identified in populations that consumed both diets rich in protein and high in carbohydrates (Lieverse, 1999: 226). When the frequencies of calculus and caries are compared, however, they can be used to assess the relative levels of proteins versus carbohydrates within a group's diet (Keenleyside, 2008: 265). Lillie (1996: 140) found that high levels of calculus were associated with low levels of caries in a population characterized by a high protein, low carbohydrate diet, while Medieval British populations, whose diet would largely have centred on cereal products, demonstrate high levels of both caries and calculus (Roberts and Cox, 2003: 258-9, 262-3).

Levels of AMTL, abscess formation and periodontal disease can provide secondary evidence in relation to diet since they can arise as a consequence of the infectious/inflammatory processes involved with the development of caries, calculus formation and/or extensive attrition (Lukacs, 1989: 271; Keenleyside, 2008: 264).

\subsection{Stable carbon and nitrogen isotopes}

Stable carbon $\left(\delta^{13} \mathrm{C}\right)$ and nitrogen $\left(\delta^{15} \mathrm{~N}\right)$ isotope analysis of bone collagen provides information on aspects of past human and animal diets. Its use has become routine in many parts of the world, and there are numerous reviews (Ambrose, 1993; Pollard, 1998). For present purposes, the most important consideration is that $\delta^{13} \mathrm{C}$ measurements clearly distinguish between $\mathrm{C}_{3}$ and $\mathrm{C}_{4}$ photosynthetic pathways, with the former including wheat and barley, and the latter comprising all the millets (including common or broomcorn millet, Panicum miliaceum, and foxtail millet, Setaria italica). Bone collagen will yield values of ca. $-21 \%$ and ca. $-5 \%$ in pure $\mathrm{C}_{3}$ and $\mathrm{C}_{4}$ consumers, respectively. The situation is made somewhat more complicated by the fact that organisms in some - though by no means all freshwater systems display elevated $\delta^{13} \mathrm{C}$ values that are intermediate between $\mathrm{C}_{3}$ and $\mathrm{C}_{4}$ systems (Dufour et al., 1999). Little is known concerning freshwater systems in the Minusinsk and Tuva Basins specifically, although the few modern fish that have been analysed from the region show depleted (i.e., $\mathrm{C}_{3}$-like) rather than elevated values (S. Svyatko 2011 pers. comm.; J. Vander Zanden 2011 pers. comm.), as do fish from the Altai region further to the west (Privat 2004; Privat et al. 2005). Further to the east, however, fish from Lake Baikal do exhibit significantly elevated $\delta^{13} \mathrm{C}$ values, although the effect may be restricted to that lake basin (Katzenberg and Weber, 1999). Other factors contributing 
to variation include the so-called canopy effect and aridity (Tieszen, 1991; Ferrio et al., 2003).

Stable nitrogen isotopes primarily reflect trophic level (Hedges and Reynard, 2007), though again there are other factors to consider, including the effects of manuring on plants (Bogaard et al., 2007; Fraser et al., 2011), and climatic effects, with aridity in particular causing elevated $\delta^{15} \mathrm{~N}$ values in both plants and animals (Ambrose, 1991; Amundson et al., 2003). Both marine and freshwater systems tend to have many more trophic levels than are found in mammalian terrestrial systems, and so tend to exhibit higher $\delta^{15} \mathrm{~N}$ values (Katzenberg and Weber, 1999; Lillie and Richards, 2000; O'Connell et al., 2003).

\section{Materials and methods}

\subsection{Osteological methods}

The dentitions of 342 adults from Aymylyrg and 44 adults from Ai-Dai were analysed (Table 1). Age-at-death and sex were determined on the basis of the standard methods outlined in Buikstra and Ubelaker (1994). Caries and abscesses were recorded macroscopically following the method of Buikstra and Ubelaker (1994: 54-55). The degree and location of calculus deposition was described following the grading system of Brothwell (1981: 155). In addition to his three categories of severity (slight, medium or considerable deposits), some individuals displayed only flecks of calculus and this was graded as 'flecks'. Individuals were ascribed a crude level of overall severity (flecks, slight, medium or considerable deposits) of calculus formation on the basis of the grade that occurred most frequently within the dentition. The identification of periodontal disease in archaeological skeletal remains is problematic, since the distance between the cementoenamel junction and the alveolar crest increases in periodontal disease, but can also arise as a result of the teeth continuously erupting to compensate for extensive attrition (Hillson, 1986: 312). Bearing these limitations in mind, the system for recording the extent of resorption of the alveolar bone devised by Brothwell (1981: 155) was followed.

Percentages were calculated for each of the different dental lesions and statistical comparisons by age and sex were conducted at both intra- and inter-site level using $\chi^{2}$ tests (with continuity correction) and Cramer's $V$. Chi-square tests are very susceptible to sample size effects, such that even very small, behaviourally meaningless, differences will 
be found to be significant with large samples. Cramer's $V$ is used to test the strength of a relationship, akin to Pearson's correlation coefficient (Cramér, 1946). Values vary between 0 (no association) and 1 (perfect association); values of ca. 0.1 or less indicate no meaningful association, regardless of the $\chi^{2}$ result. Since the age and sex profile is known to have a potential impact on interpretations of dental palaeopathology (see Keenleyside, 2008: 267), statistical analysis was undertaken to determine if any significant differences existed by age and sex in relation to the numbers of individuals and numbers of observable teeth and tooth sockets included in the study. The number of individuals does not depart significantly from equal proportions at either site (Aymyrlyg $\chi^{2}=2.25$, $\mathrm{df}=2, \mathrm{p}=0.32$; AiDai $\chi^{2}=2.22, \mathrm{df}=2, \mathrm{p}=0.33$ ), but does for both number of teeth and of sockets. However, Cramer's $V$ suggests that, despite being 'significant', neither teeth nor sockets have a meaningful association with age/sex representation at Aymyrlyg $(V=0.11$ and 0.07, respectively), while at Ai-Dai both exhibit a moderate relationship ( $V=0.31$ and 0.30 , respectively).

\subsection{Stable carbon and nitrogen isotopes}

A total of 39 human bone samples, comprising 18 (nine females and nine males) from AiDai and 21 (nine females and 12 males) from Aymyrlyg were analysed isotopically (see Table 6). With the exception of two adolescents from Ai-Dai, all samples were of adults. Unfortunately, only limited faunal material was still extant from both sites, with three samples being analysed from each site (see Table 9).

The bone collagen fraction was extracted using the ultra-filtration method (Bronk Ramsey et al., 2004; Brown et al., 1988). The bone was washed in double distilled water and a 200$250 \mathrm{mg}$ sample of interior bone was removed to minimise possibility of contamination from the bone surface. The bone sample was de-mineralised in $5 \mathrm{ml}$ of $0.5 \mathrm{M} \mathrm{HCL}$ at $60^{\circ} \mathrm{C}$ for 48-72 hours (in sealed tubes), then washed twice in double distilled water. A pH3 solution of $\mathrm{HCl}$ was added to the remaining solid and heated at $70^{\circ} \mathrm{C}$ for 24 hours to gelatinise the collagen. Samples were passed through grade 3 filter paper to remove any remaining contaminants. The solutions were then placed into $30 \mathrm{KD}$ ultrafilter centrifuge tubes (Flowgen) and centrifuged under vacuum for 10 to 20 hours at $4,000 \mathrm{rpm}$ at $40^{\circ} \mathrm{C}$, until completely filtered. The residue upon the filter was removed and re-hydrated using distilled $\mathrm{H}_{2} \mathrm{O}$ in a $5 \mathrm{ml}$ Ependorff tube, then frozen overnight and freeze dried within 24 hours. Samples were analysed for $\delta^{13} \mathrm{C}$ and $\delta^{15} \mathrm{~N}$ at Iso-Analytical using a Europa Scientific 
Roboprep elemental analyser coupled with a Europa Scientific 20-20 isotope ratio monitoring mass spectrometer. Duplicate measurements were made for one in every five samples (20\%) to test reproducibility, which was found to be $\pm 0.08 \%$ o for $\delta^{13} \mathrm{C}$ and $\pm 0.15 \%$ o for $\delta^{15} \mathrm{~N}$. Laboratory standards and a control bone sample with known $\delta^{13} \mathrm{C}$ and $\delta^{15} \mathrm{~N}$ values were also analysed for quality control purposes. Results are calculated according to the usual delta notation: (( $\left.\left.R_{\text {sample }} / R_{\text {standard }}\right)-1\right) \times 1000$, where $R$ is the isotope ratio, i.e., ${ }^{13} \mathrm{C} /{ }^{12} \mathrm{C}$ or ${ }^{15} \mathrm{~N} /{ }^{14} \mathrm{~N}$. Sample standards are VPDB for $\delta^{13} \mathrm{C}$ and AIR for $\delta^{15} \mathrm{~N}$.

\section{Results}

\subsection{Dental palaeopathology}

The most prevalent lesion for Aymyrlyg, both in terms of numbers of individuals (93.5\%) and numbers of teeth (77.2\%), was dental calculus, although this was not severe and 86.3\% of individuals displayed slight calculus formation (Tables 2 and 3). Relatively high levels of periodontal disease were also recorded (73.4\%). The frequencies of caries, abscesses and AMTL were generally similar, both in terms of the counts by individual (39.6\% to $43 \%$ ) and by tooth or socket ( $4.7 \%$ to $8.9 \%$ ). Chi-squared tests reveal no significance differences between the sexes at the individual level. Significant differences are seen between affected teeth and sockets, but Cramer's $V$ is less than 0.1 in all cases, indicating no meaningful association with sex. As might be expected, the frequencies of abscesses, AMTL and periodontal disease increase significantly with age, although caries and calculus do not.

The greatest frequencies for Ai-Dai, both in terms of numbers of individuals (97.7\%) and numbers of teeth (83.8\%), occurred for dental calculus, although this was not severe, and $83.7 \%$ of individuals displayed slight calculus formation (Tables 4 and 5). Relatively high levels of periodontal disease (79.5\%) were also present. The prevalence of abscesses and AMTL were generally similar, both in terms of the counts by individual (36.4\% and 40.9\%) and by tooth or socket (3.3\% and 6.4\%). Caries were the least frequent lesion at both individual (13.6\%) and tooth (1.9\%) level. No caries were found in 221 female teeth from 20 individuals, and this differs significantly from males (12 caries in 392 teeth from 24 individuals). Cramer's $V$ is less than 0.1 for teeth, but 0.30 for individuals, indicating that this is likely a real difference. Similarly, females show a significantly lower prevalence of abscesses at the level of the individual $\left(\chi^{2}=0.02, V=0.36\right)$ that does not convince at the level of sockets $\left(\chi^{2}=0.01, V=0.08\right)$. For all other pathologies, $V$ values are well below 0.1 
for teeth and sockets, even where $\chi^{2}$ values are less than 0.01 . The majority of lesions increase significantly in frequency for both sexes with advancing age, again with the exceptions of caries and calculus.

When the frequencies of the dental lesions at the two sites are compared it is clear that the overall trends are very similar (Figs. 3 and 4). Chi-squared tests revealed that the only significant difference between the two populations occurred in caries prevalence by individual $\left(\chi^{2}=0.001, V=0.16\right)$, and even here the strength of the association is marginal, nor does it persist at tooth level $\left(\chi^{2}<0.001, V=0.06\right)$.

\subsection{Stable isotope results}

All but one of the 39 human samples yielded acceptable results, with C:N values in the range 2.9-3.6 and collagen yields $\geq 1 \%$ (DeNiro, 1985; van Klinken, 1999) (Tables 6 and 7). The single exception, from Ai-Dai, fell just outside this range, with a C:N ratio of 3.7. It is retained in the analyses below, since its collagen yield and $\delta^{13} \mathrm{C}$ and $\delta^{15} \mathrm{~N}$ measurements are entirely within the range of the other samples; its retention or exclusion has no effect on the analysis. The average $\delta^{13} \mathrm{C}$ results of $-15.1 \pm 0.97 \%$ for Ai-Dai and $-15.3 \pm 1.25 \%$ for Aymyrlyg indicate a considerable departure from a pure $C_{3}$ system, which might be due to either a contribution from $\mathrm{C}_{4}$ plants, and/or animals feeding on them, or to fish from a freshwater system with elevated values. The average $\delta^{15} \mathrm{~N}$ results of $10.6 \pm 0.52 \%$ and $13.2 \pm 0.55 \%$ for Ai-Dai and Aymyrlyg, respectively, are fairly high, especially for Aymyrlyg. The difference between the two sites is statistically significant (Student's $t=$ 14.89, $\mathrm{df}=37, p=<0.000$ ). Moreover, the relationship between the two isotopes differs between the two sites, with no correlation at Ai-Dai $\left(r^{2}=0.0231\right)$, in contrast to a moderate but significant positive correlation at Aymyrlyg ( $\left.\mathrm{r}^{2}=0.4538 ; \mathrm{F}=15.78 ; p=0.0008\right)$. The absence of a consistent relationship between $\delta^{13} \mathrm{C}$ and $\delta^{15} \mathrm{~N}$ in the human results - such as would be expected if freshwater fish, either enriched or depleted in $\delta^{13} \mathrm{C}$, and enriched in $\delta^{15} \mathrm{~N}$, featured strongly in the diet - leads us to conclude that the elevated $\delta^{13} \mathrm{C}$ values at both sites are attributable to $\mathrm{a}_{4}$ plant, rather than to freshwater fish. This is particularly so as there is no reason to expect fish from the river systems in the study area to be enriched in $\delta^{13} \mathrm{C}$. The muscle tissue of various species of modern fish from the Eg-Uur river system in northern Mongolia averages $-28.4 \pm 2.2 \%$ o $(n=56$; J. Vander Zanden 2011 pers. 
comm.), with an inferred average bone collagen value of $-22.9 \pm 2.2 \%$ o (assuming a musclebone tissue fractionation of $+4 \%$, and a fossil fuel effect of $+1.5 \%$ (see below)).

There are no significant differences in isotopic results based on age or sex at either site, with the proviso that only adolescents and adults were sampled (Fig. 5).

The available information from Ai-Dai includes provenance to one of seven kurgans. A comparison of diets between individuals from the different kurgans is hampered by small sample size, but nevertheless some intriguing possibilities emerge. The best opportunity for a comparison comes from Kurgans 4 and 8, each represented here by five individuals: there is no difference in $\delta^{15} \mathrm{~N}$ values, but $\delta^{13} \mathrm{C}$ values appear to be higher in Kurgan 4, by ca. $1.4 \%$ (Student's t-test, unequal variance, $\mathrm{t}=2.54, p=0.044$ ) (Table 8 ). If this is indeed the case, the stable isotope data may reflect differential consumption of $\mathrm{C}_{4}$ plants within communities, a point we return to below.

Five of the six faunal samples yielded acceptable results (Table 9; see Figure 5). Sample numbers are too small to make comparisons between the species represented, but some important points emerge. First and foremost, it is clear that the four herbivores sampled predominantly consumed $C_{3}$ plants, demonstrating 1 ) that $C_{4}$ plants made up only a small proportion of the available natural vegetation (cf. Liu et al., 2004; Wang, 2003), and 2) that domestic animals were not being fed $\mathrm{C}_{4}$ plants (i.e., millet). That some $\mathrm{C}_{4}$ vegetation was present is hinted at by the elevation of ca. $2 \%$ for the $\delta^{13} \mathrm{C}$ results for two sheep/goat samples over those for single cattle and horse samples, though the numbers are too small to be entirely confident in this difference. This could also imply the use of different pastures for sheep/goat and cattle/horse, or, alternatively, the feeding preferences of these animals. The domestic dog stands out in being more similar to the humans from Ai-Dai, as is often the case, since dogs will scavenge, or be fed, much of the same foods as consumed by people.

It is also worth noting that the $\delta^{15} \mathrm{~N}$ results for the four herbivores are comparatively high (e.g., the average of 64 cattle bone values from southern British Neolithic sites is $5.3 \pm$ 0.8\%o: Hedges et al., 2007; 2008; Hamilton and Hedges, 2011). The ages of the sampled animals are not available, but it might be expected that the highest value, $9.4 \%$, is from a young animal that was still nursing, and hence elevated above adult values. Excluding this, 
the remaining three herbivore samples still average ca. 6.9\%o. However, this is not unusual for steppe environments, with similarly elevated values being reported elsewhere (Privat, 2004; Shishlina et al., 2007; Hollund et al., 2010), probably due to aridity/salinity effects (Heaton, 1987; Ambrose, 1991; Amundson et al., 2004).

\section{Discussion}

\subsection{Dental palaeopathology}

The dental palaeopathological lesions suggest that the diets consumed by the Aymyrlyg and Ai-Dai population groups were very similar and were broadly characterized by high frequencies of slight deposits of calculus and low to moderate levels of caries. The frequencies of caries correspond best to Turner's (1979) scheme for foraging or mixed foraging/agricultural populations. The archaeological and anthropological evidence indicates that both populations were largely pastoralists and, as such, they are likely to have consumed high levels of animal products. Indeed, the occurrence of very high frequencies of calculus deposits for both populations would tend to support this finding. The availability of published comparative dental palaeopathological data for prehistoric Eurasian steppe populations is very limited but a review of the available information can aid with the interpretation of the findings of the current study. Both Lillie (1996) and Murphy (forthcoming) found that caries were almost universally absent amongst Mesolithic-Late Bronze Age Eurasian populations considered to have largely practiced foraging/pastoralist economies. An examination of the dental palaeopathology of a small group of Xiongnu individuals from the cemetery of Naima Tolgoy, Mongolia, and described as nomadic, revealed that none of their teeth displayed caries. This finding was not considered unexpected since the diet was not believed to have been cariogenic (RegölyMérei, 1967: 407). As such, it can be concluded that the individuals from both Aymyrlyg and Ai-Dai were consuming cereals but it is not possible to ascertain whether these were wild or domesticated on the basis of dental palaeopathology alone. The caries prevalences would tend to suggest that cereals did not form the main component of their diet, however, but rather represented a supplementary aspect of the subsistence economy. Eng (2007) undertook a biocultural study of a series of populations - referred to as nomadic pastoralist, agropastoralist and agricultural - in northern China, part of which involved an assessment of the impact of subsistence strategy on dental health. The results for the agricultural populations were considered anomalous since they displayed low frequencies of caries that were explained as a result of the relatively small samples size. The caries 
frequencies by individual for the nomadic pastoralists (27\%) and agropastoralists (56\%) were characteristic of significant carbohydrate consumption. The prevalence for the nomadic pastoralists was most similar to the results obtained from Aymyrlyg (39.6\%) and Ai-Dai (13.6\%), while the prevalence for the agropastoralists was, perhaps surprisingly, notably higher. Unfortunately, information for other dental palaeopathologies did not form part of the study of the northern China groups.

When the lesions were compared by sex at intra-site level the only convincing statistical differences occurred for caries and abscess prevalence at Ai-Dai. Males were more susceptible to the development of these lesions, perhaps indicating differential levels of cereal consumption. Vainshtein (1980: 90-91) discusses pastoralist and cultivation strategies in twentieth-century Tuva in which a clear gender division of labour is evident. Males were largely responsible for tending crops and spent periods of time distant from the women and children when undertaking this work. Harvesting, however, appears to have been undertaken by all members of the unit (Vainshtein, 1980: 156). Perhaps similar gender labour divisions in the past facilitated differential access to food resources. The lack of comparable sex differences at Aymyrlyg, however, clearly underlines the complexity and variability of pastoral strategies.

Although the frequencies of calculus were very high at both Ai-Dai and Aymyrlyg, the deposits were generally slight. While the prevalences appear to broadly correlate with those obtained by Lillie (1996) for a high protein, low carbohydrate diet, the pattern of severity appears to be different. Medium to heavy deposits of calculus had a 'consistent presence' within the Mesolithic-Neolithic Ukrainian groups (Lillie, 1996: 140), whereas both the Aymyrlyg and Ai-Dai series were almost ubiquitously characterized by slight deposits. Although the aetiology of calculus has been shown to be extremely complex (see Lieverse, 1999), it is tempting to suggest that this difference is, at least in part, due to a higher level of carbohydrate consumption among the Iron Age populations.

\subsection{Stable carbon and nitrogen isotopes}

There is little doubt that the $\mathrm{C}_{4}$ plant responsible for the unexpectedly high $\delta^{13} \mathrm{C}$ values at Ai-Dai and Aymyrlyg was cultivated millet. We base this conclusion on two lines of evidence. First, the limited number of herbivores measured in this study, alongside the much larger numbers from elsewhere on the eastern Eurasian steppes (Privat 2004; Privat 
et al., 2005), are clearly indicative of predominantly $C_{3}$ diets, in keeping with the variable but generally low prevalence of wild $\mathrm{C}_{4}$ plants in the region (cf. Wang 2003; Liu et al., 2004). Secondly, elevated $\delta^{13} \mathrm{C}$ values are not seen on earlier Bronze Age humans in the Minusinsk Basin as would be expected if wild $\mathrm{C}_{4}$ plants made an important dietary contribution in this region (Svyatko, 2009; Svyatko et al., submitted; see also Privat et al., 2005, for the Late Bronze Age to Iron Age site of Čiča, further to the west). While wild $\mathrm{C}_{4}$ grasses (e.g., Chenopodium spp.) may have on occasion been consumed, they would have had to have been a staple part of the long-term diet to result in the observed $\delta^{13} \mathrm{C}$ values (recall that measurements on bone collagen reflect the averaged diet over the last decade or so of life). Similar arguments have long been made when tracing the spread of another $\mathrm{C}_{4}$ crop, maize (Zea mays), in North America (Vogel and van der Merwe, 1977; Katzenberg et al., 1995; Schurr and Schoeninger, 1995), where, it should be noted, wild $\mathrm{C}_{4}$ chenopods were also present.

In can therefore be concluded that crop-based agriculture, and specifically millet, played a much larger role in the Iron Age steppe communities of the Minusinsk and Tuva Basins than has previously been recognised. It is possible to make a rough calculation of the dietary contribution of millet at the two sites. Measurements of modern broomcorn (Panicum miliaceum) and foxtail (Setaria italica) millet from various locations around the world average $-11.8 \pm 1.1 \%$ o $(n=17)$ for $\delta^{13} \mathrm{C}$ (Bender, 1968; Minagawa, 1992; McGovern et al., 2004; Schwarz and White, 2004; Pechenkina et al., 2005). This needs to be adjusted by ca. $+1.5 \%$ to take into account depletion in the world's atmospheric $\delta^{13} \mathrm{C}$ reservoir by the burning of fossil fuels (the 'Suess effect', Keeling, 1979) over the last few centuries, resulting in a postulated pre-modern average of $-10.3 \pm 1.1 \%$. By contrast, $\mathrm{C}_{3}$ plants, including wheat and barley, exhibit $\delta^{13} \mathrm{C}$ values of ca. -27\%o (O'Leary, 1988), which again need to be corrected by $+1.5 \%$. With a fractionation from diet to bone collagen of ca. $+5 \% 0$ (Lee-Thorp et al., 1989), the endpoints for pure $\mathrm{C}_{3}$ and $\mathrm{C}_{4}$ diets in pre-industrial human consumers can be given as ca. $-20.5 \%$ and ca. $-5.5 \%$, respectively. Although not directly relevant for the present calculation, it is worth noting that, on the basis of what little $\delta^{15} \mathrm{~N}$ data are available for millet, a value of $3.0 \pm 1.1 \%$ can be proposed $(n=7)$ (Minagawa, 1992; McGovern et al., 2004; Pechenkina et al., 2005).

Assuming a simple linear mixing model between dietary intake and the resulting $\delta^{13} \mathrm{C}$ values in bone collagen (Phillips and Gregg, 2003; see also Hu et al., 2008), the average of 
ca. $-15 \%$ for humans from both Ai-Dai and Aymyrlyg equates to an estimate of ca. $35 \pm$ $10 \%$ (i.e., approximately one-third) contribution of millet to the diet (the error term informally reflecting various sources of uncertainty). If anything, this is likely to be a conservative estimate, since the protein found in millet is of relatively low quality, being particularly deficient in the essential amino acid lysine (Hulse et al., 1980), and so will be under-represented in measurements on bone collagen, which are biased towards the protein component of the diet (Ambrose and Norr, 1993; Jim et al., 2006). It can be predicted, therefore, that the analysis of enamel carbonate (bioapatite), which reflects the energy component of the diet, would indicate a somewhat higher millet contribution. Lacking gluten, millets are unsuited for leavened breads, but may be used to make flat bread, porridges, or weak alcoholic beverages such as kvass. The latter possibility is particularly interesting in light of the apparent differential consumption of millet between those buried in different kurgans at Ai-Dai.

A further implication of the considerable contribution of millet to human diets at Ai-Dai and Aymyrlyg is that other cereals known to have been cultivated, such as barley, were almost certainly also grown in quantity. Their contribution would be masked isotopically by other foods, including that supplied by animals grazing predominantly on $\mathrm{C}_{3}$ plants. Taken together, then, it might be suggested that more than half the diet was derived from cultivated cereals. This raises the question of the origin of these crops, which, given its proximity, is presumably north-west China, where millet has been documented from before $7000 \mathrm{cal} \mathrm{BP}$, both as charred remains and through stable carbon isotope analyses (Barton et al., 2008; Hu et al., 2008). There are, however, large gaps both spatially and temporally in our knowledge of its spread across northern Eurasia (Hunt et al., 2008) so that at present it is difficult to provide more detail on the timing and routes taken with respect to Tuva and the Minusinsk Basin. The former question at least is addressed in a forthcoming paper (Svyatko et al., submitted).

Turning to the solely protein component of the diet represented by $\delta^{15} \mathrm{~N}$ measurements, the best available baseline derives from the four herbivores, averaging ca. 7.5\%o. Assuming a trophic level fractionation of 3-4\%, human consumers relying predominantly on animal protein (meat, milk, blood) would be expected to have values of ca. $11.0 \%$. This is not incompatible with the observed average of $10.6 \%$ for Ai-Dai, but cannot account for the substantially higher average of $13.2 \%$ for Aymyrlyg, and other protein sources with higher 
$\delta^{15} \mathrm{~N}$ values must feature in the diet at this site. Freshwater fish offer one possibility, and can be suggested to have made a significant contribution to human diets at Aymyrlyg. While we have no fish isotope values from the site itself, nor from its immediate environs, modern taimen (Hucho taimen) from the Eg-Uur river system of northern Mongolia exhibit $\delta^{15} \mathrm{~N}$ values of $14.1 \pm 1.2 \%$ o $(\mathrm{n}=18)(\mathrm{J}$. Vander Zanden 2011 pers. comm.). The likelihood is that fish also featured, albeit to a far lesser extent, at Ai-Dai. This is because it is improbable that the Ai-Dai community obtained all of their protein from animal sources, particularly given the evidence for a substantial contribution from millet, with its very low $\delta^{15} \mathrm{~N}$ values. The seeming importance of freshwater fish in the diets of Eurasian and Central Asian steppe populations is being increasingly acknowledged, largely as a result of stable isotope studies (O'Connell et al., 2003; Privat, 2004; Privat et al., 2005; Shishlina et al., 2007).

Before accepting fish as the likely 'missing component' responsible for the elevated human $\delta^{15} \mathrm{~N}$ values, and more specifically the difference in $\delta^{15} \mathrm{~N}$ between the two sites, a potentially confounding factor must be considered. Studies have demonstrated that $\delta^{15} \mathrm{~N}$ values increase in soils, plants and animals under conditions of aridity and soil salinity (Heaton, 1987; Ambrose 1991; Gröcke et al., 1997; Schwarcz et al., 1999; Robinson, 2001; Amundson et al., 2003). The very definition of mid-latitude steppe, like those of the Minusinsk and Tuva basins, is a grassland with low annual precipitation, on the order of 250-500 mm (Nicholson, 2011). Crucially, in terms of the present study, modern precipitation on the steppes of Tuva is even lower than that of the Minusinsk Basin, ranging from 100 to $250 \mathrm{~mm}$ annually, although increasing with elevation, from 300-400 mm in the mountain forest-steppe up to 600-700 mm in the tundra highlands (Khrutskyi, 1997, cited in Stebaeva, 2003: 342). The closest meteorological station to Aymyrlyg is at Chadan, Tuva Republic, where average annual rainfall over the last decade is recorded as $260 \mathrm{~mm}$, while the closest stations to Ai-Dai are at Minusinsk and Abakan, with average annual rainfall of 353 and $320 \mathrm{~mm}$, respectively (http://www.weatherbase.com/).

Whether modern precipitation values can be applied to the first millennium BC is open to question - indeed, this period seems to have seen an increase in moisture that is held to be responsible for the sudden increase in archaeological activity, and hence inferred population, from ca. 750 cal BC (van Geel et al., 2004; Zaitseva et al., 2004) - but the pattern is likely to have remained the same. It is around $200-300 \mathrm{~mm}$ annual precipitation that aridity effects become particularly evident (Murphy and Bowman, 2006). Hollund et al. 
(2010: fig. 11) demonstrate a clear negative correlation between rainfall and human $\delta^{15} \mathrm{~N}$ measurements from a series of Bronze Age sites in the North Caucasus. The highest values, averaging ca. 14\%o, are seen in regions with annual precipitation of ca. $300 \mathrm{~mm}$, decreasing to values of ca. $10-11 \%$ in regions where rainfall increases to ca. $700 \mathrm{~mm}$. The latter figure, however, is substantially higher than that recorded near Ai-Dai in recent times, so that it is not clear to what extent differential aridity might explain the observed difference between the two sites. Indeed, based on the very limited faunal samples - a single herbivore from Ai-Dai and three from Aymyrlyg - the $\delta^{15} \mathrm{~N}$ values from the two basins appear similar, suggesting that 1 ) the human inter-site differences are probably real, and 2) that they are only partly the result of aridity effects. Clearly, however, additional faunal and floral samples are needed to confirm both points.

\subsection{The two dietary proxies compared}

No correlation was found between individuals with and without caries and $\delta^{13} \mathrm{C}$ values at either Ai-Dai or Aymyrlyg, such as might be expected if high millet consumption resulted in increased propensity to develop caries (Table 10). In particular, the greater prevalence of caries in males at Ai-Dai is not matched by higher $\delta^{13} \mathrm{C}$ values. Calculus deposits are nearly ubiquitous, but generally slight, in both populations, with no clear relationship with $\delta^{13} \mathrm{C}$ or $\delta^{15} \mathrm{~N}$ results, although this comparison is hampered by low sample numbers (particularly as nearly $50 \%$ of the Aymyrlyg skeletons available for sampling for isotopic analyses lacked dentition). Other palaeopathological conditions were not tested against the isotopic data as, firstly, there is no theoretical reason to expect any relationship between them, and, secondly, the same problem of small sample size arises.

\section{Conclusions}

The results of the current study have demonstrated that the two Early Iron Age populations at Ai-Dai and Aymyrlyg display isotopic signatures indicative of varying, but substantial, consumption of millet - contributing approximately one-third of the dietary protein for these populations. While the evidence derived from the frequencies of caries is less definitive it is also suggestive that carbohydrates formed a component of both diets. Even in relatively recent years the Tagar Culture has been considered to comprise a 'pure' nomadic culture with an emphasis on stock-breeding (van Geel et al., 2004: 1739). Yet many strands of anthropological and archaeological evidence amassed from the mid twentieth-century onwards have suggested an agricultural component to the economy of 
both the Uyuk and Tagar Cultures (e.g. Okladnikov, 1959; Zavitukhina, 1978; Vainshstein, 1980). Its extent and importance, however, remained uncertain and some researchers were of the opinion that agricultural products may have entered the archaeological record simply as a result of trade (e.g. Mandelshtam, 1992: 193). In the light of the present study, this seems very unlikely - the isotopic evidence suggests that the consumption of millet was too high and too persistent to reflect occasional trade. In addition, millet would be an unlikely candidate for bulk trade over any distance. Whether wild cereals were also being exploited by Tagar groups, as Bokovenko (2006: 877) suggested, cannot be determined on the basis of the stable isotope data, but would probably be unnecessary given the presence of more productive cultigens indicated in our study. The source of the millet presumably ultimately lies in north-west China, but there remain large gaps in our knowledge concerning its transmission.

Our results complement those of previous researchers on the Eastern steppe. Geoarchaeological and environmental research at Semirechye in Kazakhstan has revealed evidence for the production of domestic cereals around 750 BC by the Iron Age Saka (Miller Rosen et al., 2000; Chang et al., 2003). Problems of classification and terminology have been inherent in archaeological studies of pastoral nomadism and it has been suggested that the term 'mobile pastoralism' is used as a general phrase to refer to a subsistence economy that emphasizes mobility and pastoral management (Frachetti, 2008: 16-17). This term is defined as a form of animal keeping that is more intensive and specialised than tethered agropastoralism (Frachetti, 2012: 7). The use of this blanket term gives recognition to the highly variable and flexible practices that can exist within nomadism (Salzman, 2002: 249). It is possible that problems with terminology were, at least in part, responsible for the hazy understanding of the subsistence strategies of the Uyuk and Tagar Cultures that this study has attempted to clarify.

Di Cosmo (1994: 1100) cites an ethnographic example from the Selenga Valley, near Lake Baikal in southern Siberia, which provides insights concerning the traditional methods of land tillage employed by nomadic pastoralists. Farming activities occurred on strips of land near river banks. The soil was broken open using wooden plows and the clods of earth were worked by the naked hand, following which wheat, barley or rye seeds were sown. The nomads then moved on to their summer pastures, returning to harvest their crops in the autumn. Much of the harvesting and processing of crop was undertaken either by hand 
or with the use of wooden tools. This account is illuminating because it might help explain the apparent paucity of agricultural tools in the archaeological record for these ostensibly nomadic pastoralist groups (Di Cosmo, 1994: 1100). The focus of farming activities alongside river banks is also informative - since both Ai-Dai and Aymyrlyg were located adjacent to rivers.

The individuals from both Ai-Dai and Aymyrlyg included in the study derived from kurgan cemeteries. It is thought that such burial traditions are characteristic of a society based on tribal family units. The burials are thought to have been concentrated in clusters and small groups to demarcate certain tribal groups (Abetekov and Yusupov 1994, 26). Neither burial ground was considered to display extremes of wealth and indeed, with respect to Aymyrlyg, the excavator concluded that the society was generally 'egalitarian' (Mandelshtam 1992: 194). Di Cosmo (1994: 1104) offered the view that in the KhakassMinusinsk region a balanced economy which involved floodplain farming, animal breeding and hunter-gathering was characteristic of the Tagar culture but that this changed during the second century BC as a consequence of the Xiongnu invasion into the region. He suggested that the succeeding Tashtyk period saw a more notable economic division between stock-breeders and those who practiced crop-based agriculture, although farming still remained the main economic activity. Tuva is also believed to have experienced the full impact of the Xiongnu invasion (see Murphy 2012) and it is possible that a similar change in economic practices and social structure may also have occurred in this region. As such, concurring with Di Cosmo (1994: 1104), we can imagine a scenario in which the militarily superior Xiongnu nomadic groups wielded political and military power over a region which had included scattered communities who practiced seasonal floodplain farming in addition to stockbreeding. It is clear that a more intricate understanding of the economic strategies of mobile pastoralists has the potential to provide insights concerning the nature of social complexity and change amongst these prehistoric groups.

While it has long been recognized that the cultural horizons that form the Scythian World only share certain general similarities (see Yablonsky, 2000) it has still been largely assumed that a pastoral nomadic economy is one such shared trait (e.g. Moškova, 1994: 232). While the nature of the economy may broadly be categorized in this manner it is clear that populations in both Tuva and the Minusinsk Basin practiced a complex mobile pastoralist economy which included a significant degree of agriculture, and, in all 
likelihood, considerable use of freshwater fish. It is with regard to the latter that the two sites appear to differ most strongly, based on the $\delta^{15} \mathrm{~N}$ evidence. In addition to the broad variation discussed above, there are hints of differential access to millet within the Ai-Dai community, although this remains a tentative hypothesis pending the analysis of additional samples. The paucity of faunal samples from the two regions discussed in the paper presents limits on interpretation. In particular, it is difficult to choose between the importance of fish and aridity effects in the explanation of elevated $\delta^{15} \mathrm{~N}$ values seen at to some extent at Ai-Dai, but far more clearly at Aymyrlyg, though at present the balance of evidence points to the former.

This study, with its focus on two Siberian sites, has greatly refined our understanding of the complex subsistence strategies employed by these Iron Age mobile pastoralists. There remain, however, major gaps in the understanding of the economic strategies employed by the prehistoric populations across the vast Eurasian steppe. Further isotopic and dental palaeopathological studies of additional sites and regions, with increased sample sizes, could enable much more to be learned of the broad range of subsistence strategies employed by the diverse steppe cultures which fall under the umbrella term of 'mobile pastoralists'. Furthermore, a multidisciplinary approach which involves the integration of data derived directly from human skeletal remains with an array of information obtained from landscape surveys and the excavation of habitation sites has the potential to completely revolutionise our understanding of the complex social structures and subsistence strategies operated by the prehistoric peoples of the Eurasian steppe.

\section{Acknowledgements}

The authors would like to thank Iso-Analytical, Sandbach, Cheshire, for providing financial support in the form of a European student award to Dr. Nick Beer. We are also grateful to Professor Mike Richards, Department of Anthropology, University of British Columbia, for advice regarding collagen extraction, and to Professor Christine Maggs and Dr. Vicky Kett for providing laboratory facilities in the School of Biological Sciences, Queen's University Belfast. Thanks are also due to Ms. Libby Mulqueeny, School of Geography, Archaeology and Palaeoecology, Queen's University Belfast, for preparing Figure 1. Finally, the authors would like to express their appreciation for the detailed comments and suggestions made by four anonymous reviewers. 


\section{References}

Abetekov, A., Yusupov, H., 1994. Ancient Iranian Nomads in Western Central Asia, in: Harmatta, J. (Ed.), History of Civilisations of Central Asia, Vol. III, The Development of Sedentary and Nomadic Civilisations: 700 BC to AD 250, UNESCO, Paris, pp. 23-33.

Ambrose, S.H., 1991. Effects of diet, climate and physiology on nitrogen isotope abundances in terrestrial foodwebs. J. Archaeol. Sci. 18, 293-317.

Ambrose, S.H., 1993. Isotope analysis of paleodiets: methodological and interpretive considerations, in: Sandford, M.K. (Ed.), Investigations of Ancient Human Tissue: Chemical Analyses in Anthropology. Gordon and Breach, Langhorne, Pennsylvania, pp. 59-130.

Ambrose, S.H., Norr, L., 1993. Experimental evidence for the relationship of the carbon isotope ratios of whole diet and dietary protein to those of bone collagen and carbonate, in: Lambert, J.B., Grupe, G. (Eds.), Prehistoric Human Bone: Archaeology at the Molecular Level, Springer-Verlag, New York, pp. 1-37.

Amundson, R., Austin, A.T., Schuur, E.A.G., Yoo, K., Matzek, V., Kendall, C., Uebersax, A., Brenner, D., Baisden, W.T., 2003. Global patterns of isotopic composition of soil and plant nitrogen. Glob. Biogeochem. Cycl. 17, 1031-1042.

Anthony, D.W., Brown, D., Brown, E., Goodman, A., Kokhlov, A., Kosintsev, P., Kuznetsov, P., Mochalov, O., Murphy, E., Peterson, D., Pike-Tay, A., Popova, L. and Weisskopf, A., 2005. The Samara Valley Project: Late Bronze Age economy and ritual in the Russian steppes. Eur. Ant. 11, 395-417.

Barfield, T. J., 1993. The Nomadic Alternative, Prentice Hall, Englewood Cliffs.

Barton, L., Newsome, S.D., Chen, F.-H., Wang, H., Guilderson, T.P., and Bettinger, R.L., 2009. Agricultural origins and the isotopic identity of domestication in northern China. Proc. Nat. Acad. Sci. 106, 5523-5528.

Bender, M.M., 1968. Mass spectrometric studies of carbon 13 variations in corn and other grasses. Radiocarb. 10, 468-472.

Bogaard, A., Heaton, T.H.E., Poulton, P., Merbach, I., 2007. The impact of manuring on nitrogen isotope ratios in cereals: archaeological implications for reconstruction of diet and crop management practices. J. Archaeol. Sci. 34, 335-343.

Bokovenko, N.A., 1995. Tuva during the Scythian period, in: Davis-Kimball, J., Bashilov, V.A., Yablonsky, L.T. (Eds.), Nomads of the Eurasian Steppes in the Early Iron Age, Zinat Press, Berkeley, pp. 265-281.

Bokovenko, N., 2006. The emergence of the Tagar culture. Ant. 80, 860-879.

Bronk Ramsey, C., Higham, T., Bowles, A., Hedges, R., 2004. Improvements to the pretreatment of bone at Oxford. Radiocarb. 46, 155-163.

Brown, T.A., Nelson, D.E., Southon, J.R., 1988. Improved collagen extraction by modified Longin method. Radiocarb. 30, 171-177. 
Brothwell. D.R., 1981. Digging up Bones, third ed. British Museum/Cornell University Press, New York.

Buikstra, J., Ubelaker, D.H. (Eds.), 1994. Standards for Data Collection from Human Skeletal Remains, Arkansas Archeological Survey Research Series No. 44. Arkansas Archeological Survey, Arkansas.

Chang, C., Benecke, N., Grigoriev, F.P., Rosen, A.M., Tourtellotte, P.A., 2003. Iron Age society and chronology in South-east Kazakhstan. Ant. 77, 298-312.

Cramér, H., 1946. Mathematical Methods of Statistics. Princeton Univeristy Press, Princeton.

Crawford, M.H., Leonard, W.R., 2002. The biological diversity of herding populations: An introduction, in: Leonard, W.R., Crawford, M.H. (Eds.), Human Biology of Pastoral Populations, Cambridge University Press, Cambridge, pp. 1-9.

Cribb, R., 1991. Nomads in Archaeology. Cambridge University Press, Cambridge.

Cucina, A., Tiesler, V., 2003. Dental caries and ante-mortem tooth loss in the Northern Peten area, Mexico: a biocultural perspective on social differences among the Classic Maya. Am. J. Phys. Anthropol. 122, 1-10.

DeNiro, M.J., 1985. Post-mortem preservation and alteration of in vivo bone collagen isotope ratios in relation to palaeodietary reconstruction. Nat. 317, 806-809.

Di Cosmo, N., 1994. Ancient Inner Asian nomads: their economic basis and its significance in Chinese history. J. Asian Stud. 53, 1092-1126.

Di Cosmo, N., 2002. Ancient China and its Enemies: The Rise of Nomadic Power in East Asian History. Cambridge University Press, Cambridge.

Dufour, E., Bocherens, H., Mariotti, A., 1999. Palaeodietary implications of isotopic variability in Eurasian lacustrine fish. J. Archaeol. Sci. 26, 617-627.

Eng, J.T., 2007. Nomadic Pastoralists and the Chinese Empire: A Bioarchaeological Study of China's Northern Frontier. PhD Dissertation in Anthropology, University of California Santa Barbara (UMI Number: 3283707).

Ermolova, N.M., 1983. Novye dannye po istorii ohoty i skotovodstva na yuge Sibiri, in: Drevniye Kultury Euraziiskih Stepei, Institute for the History of Material Culture, Leningrad, pp. 103-107 (in Russian).

Ferrio, J.P., Voltas, J., Araus, J.L., 2003. Use of carbon isotope composition in monitoring environmental changes. Manag. Environ. Qual.: Int. J. 14, 82-98.

Frachetti, M.D., 2008. Pastoralist Landscapes and Social Interaction in Bronze Age Eurasia. University of California Press, London.

Frachetti, M.D., 2012. Multiregional emergence of mobile pastoralism and nonuniform 
institutional complexity across Eurasia. Current Anthropology 53, 2-38.

Fraser, R.A., Bogaard, A., Heaton, T.H.E., Charles, M., Jones, G., Christensen, B.T., Halstead, P., Merbach, I., Poulton, P.R., Sparkes, D., Styring, A.K., 2011. Manuring and stable nitrogen isotope ratios in cereals and pulses: towards a new archaeobotanical approach to the inference of land use and dietary practices. J. Archaeol. Sci. 38, 2790-2804.

Gracheva, R.G., 2004. Cryosols of the mountains of southern Siberia and Far Eastern Russia, in: Kimble, J. M. (Ed.), Cryosols: Permafrost-Affected Soils. Springer, New York, pp. 231252.

Gröcke, D.R., Bocherens, H., Mariotti, A., 1997. Annual rainfall and nitrogen-isotope correlation in macropod collagen: application as a palaeoprecipitation indicator. Earth Planet. Sci. Lett. 153, 279-286.

Gryaznov, M.P., 1969. The Ancient Civilization of South Siberia. Barrie \& Rockliff, The Cresset Press, London.

Hamilton, J., Hedges, R.E.M., 2011. Carbon and nitrogen stable isotope values of animals and humans from causewayed enclosures, in: Whittle, A., Healy, F., Bayliss, A. (Eds.), Gathering Time: Dating the Early Neolithic Enclosures of Southern Britain and Ireland, Oxbow, Oxford, pp. 670-681.

Heaton, T.H.E., 1987. The ${ }^{15} \mathrm{~N} /{ }^{14} \mathrm{~N}$ ratios of plants in South Africa and Namibia: relationship to climate and coastal/saline environments. Oecologia 74, 236-246.

Hedges, R.E.M., Reynard, L.M., 2007. Nitrogen isotopes and the trophic level of humans in archaeology. J. Archaeol. Sci. 34, 1240-1251.

Hedges, R.E.M., Saville, A., O'Connell, T.C., 2008. Characterizing the diet of individuals at the Neolithic chambered tomb of Hazleton North, Gloucestershire, England, using stable isotope analysis. Archaeometry 50, 114-128.

Hedges, R.E.M., Stevens, R.E., Pearson, J.A., 2007. Carbon and nitrogen stable isotope compositions of animal and human bone, in: Benson, D., Whittle, A. (Eds.), Building Memories: the Neolithic Cotswold Long Barrow at Ascott-under-Wychwood, Oxfordshire, Oxbow, Oxford, pp. 255-262.

Hanks, B., 2010. Archaeology of the Eurasian steppes and Mongolia. Annu. Rev. Anthropol. 39, 469-486.

Hillson, S., 1996. Dental Anthropology. Cambridge University Press, Cambridge.

Hillson, S., 2000. Dental pathology, in: Katzenberg, M.A., Saunders, S.R. (Eds.), Biological Anthropology of the Human Skeleton, Wiley-Liss, Chichester, pp. 249-286.

Hollund, H.I., Higham, T., Belinskij, A., Korenevskij, S., 2010. Investigation of palaeodiet in the North Caucasus (South Russia) Bronze Age using stable isotope analysis and AMS dating of human and animal bones. J. Archaeol. Sci. 37, 2971-2983. 
Hu, Y., Wang, S., Luan, F., Wang, C., Richards, M.P., 2008. Stable isotope analysis of humans from Xiaojingshan site: implications for understanding the origin of millet agriculture in China. J. Archaeol. Sci. 35, 2960-2965.

Hulse, J.H., Laing, E.M., Pearson, O.E., 1980. Sorghum and the Millets: Their Composition and Nutritional Value. Academic Press, New York.

Hunt, H.V., Vander Linden, M., Liu, X., Motuzaite-Matuzeicuite, G., Colledge, S., Jones, M.K., 2008. Millets across Eurasia: chronology and context of early records of the genera Panicum and Setaria from archaeological sites in the Old World. Veg. Hist. Archaeobot. 17, 5 -18 .

Jim, S., Jones, V., Ambrose, S.H., Evershed, R.P., 2006. Quantifying dietary macronutrient sources of carbon for bone collagen biosynthesis using natural abundance stable carbon isotope analysis. Br. J. Nutr. 95, 1055-1062.

Katzenberg, M.A., Schwarcz, H.P., Knyf, M., Melby, F.J., 1995. Stable isotope evidence for maize horticulture and paleodiet in southern Ontario, Canada. Am. Antiq. 60, 335-350.

Katzenberg, M.A., Weber, A., 1999. Stable isotope ecology and palaeodiet in the Lake Baikal region of Siberia. J. Archaeol. Sci. 26, 651-659.

Keeling, C.D., 1979. The Suess effect: 13Carbon-14Carbon interrelations. Environ. Int. 2, 229-300.

Keenleyside, A., 2008. Dental pathology and diet at Apollonia, a Greek colony on the Black Sea. Int. J. Osteoarch. 18, 262-279.

Khazanov, A.M., 1984. Nomads and the Outside World. Cambridge University Press, Cambridge.

Kohl, P.L., 2007. The Making of Bronze Age Eurasia. Cambridge University Press, Cambridge.

Koryakova, L., Epimakhov, A.V., 2006. The Urals and Western Siberia in the Bronze and Iron Ages. Cambridge University Press, Cambridge.

Kuzmin, N. Yu., 2008. Prospects for correlating radiocarbon and archaeological chronologies of the Scythian and Hunno-Sarmatian age burials in the Sayan-Altai region. Arch. Ethnol. Anthropol. Eurasia 35, 77-87.

Larsen, C.S., 1995. Biological changes in human populations with agriculture. Annu. Rev. Anthropol. 24, 185-213.

Larsen, C.S., 1997. Bioarchaeology: Interpreting Behavior from the Human Skeleton. Cambridge University Press, Cambridge.

Lee-Thorp, J., Sealy, J., and van der Merwe, N.J., 1989. Stable carbon Isotope ratio differences between bone collagen and bone apatite, and their relationship to diet. J. Archaeol. Sci. 16, 585-599. 
Lieverse, A.R., 1999. Diet and the aetiology of dental calculus. Int. J. Osteoarch. 9, 219-232.

Lillie, M.C., 1996. Mesolithic and Neolithic populations of Ukraine: indications of diet from dental pathology. Curr. Anthropol. 37, 135-142.

Lillie, M.C., Richards, M., 2000. Stable isotope analysis and dental evidence of diet at the Mesolithic-Neolithic transition in Ukraine. J. Archaeol. Sci. 27, 965-972.

Liu, X.Q., Wang, R.Z., Li, Y.Z., 2004. Photosynthetic pathway types in rangeland plant species from Inner Mongolia, North China. Photosynthetica 42, 339-344.

Lukacs, J.R., 1989. Dental palaeopathology: methods for reconstructing dietary patterns, in: İsçan, M.Y. and Kennedy, K.R. (Eds.), Reconstruction of Life from the Skeleton, Wiley-Liss, Chichester, pp. 261-286.

Lukacs, J.R., 1996. Sex differences in dental caries rates with the origin of agriculture in south Asia. Curr. Anthropol. 37, 147-153.

Mandelshtam, A.M., 1983. Issledovaniye na mogilnom polye Aymyrlyg: Nekotoriye itovi i perspektii, in: Drevniye Kulturi Euraziiskih Stepei, Institute for the History of Material Culture, Leningrad, pp. 25-33 (in Russian).

Mandelshtam, A.M., 1992. Ranniye kochevniki Skifskova perioda na territorii Tuvi, in: Moshkova, M.G. (Ed.), Stepnaya Polosa Aziatskoi Chasti SSSR v Skifo-Sarmatskoye Vremya, Archeologiya SSSR, Nauka, Moskva, pp. 178-196 (in Russian).

Mannai-Ool, M.H., 1970. Tuva v Skifskoye Vremya (Uyukskaya Kultura). Nauka, Moscow (in Russian).

McGovern, P.E., Zhang, J., Tang, J., Zhang, Z., Hall, G.R., Moreau, R.A., Nuñez, A., Butrym, E.D., Richards, M.P., Wang, C.-S., Cheng, G., Zhao, Z., Wang, C., 2004. Fermented beverages of preand proto-historic China. Proc. Natl. Acad. Sci. USA 101, 17593-17598.

Michczynski, A., 2004. Problems of construction of a radiocarbon chronology for the time period 900-300 cal BC, in: Scott, E.M., Alekseev, A.Y., Zaitseva, G. (Eds.), Impact of the Environment on Human Migration in Eurasia, Kluwer, Dordrecht, pp. 117-123.

Miller Rosen, A., Chang, C., Grigoriev, F.P., 2000. Palaeoenvironments and economy of Iron Age Saka-Wusun agro-pastoralists in southeastern Kazakhstan. Antiq. 74, 611-623.

Minagawa, M., 1992. Reconstructi Moškova on of human diet from 13C and 15N in contemporary Japanese hair: a stochastic method for estimating multi-source contribution by double isotopic traces. Appl. Geochem. 7, 145-158.

Moškova, M.G., 1994. On the nature of the similarity and difference in the nomadic cultures of the Eurasia steppes of the 1st Millennium BC, in: Genito, B. (Ed.), The Archaeology of the Steppes: Methods and Strategies, Instituto Universitario Orientale, Naples, pp. 231-241.

Murphy, B.P., Bowman, D., 2006. Kangaroo metabolism does not cause the relationship 
between bone collagen $\delta^{15} \mathrm{~N}$ and water availability. Funct. Ecol. 20, 1062-1069.

Murphy, E.M., 2012. A Bioarchaeological Study of Xiongnu Expansion in Iron Age Tuva, South Siberia, in: Hartley, C.W., Yazicioğlu, G.B. and Smith, A.T. (Eds.), Regimes and Revolutions: Power, Violence, and Labor in Eurasia from the Ancient to the Modern, Cambridge University Press, Cambridge, pp. XXXX.

Murphy, E.M., forthcoming. Biocultural analysis of the prehistoric populations of the Volga region, in: Anthony, D., Brown, D., Khokhlov, A., Kuznetsov, P. and Mochalov, O. (Eds.), The Samara Valley Project: Bronze Age Pastoralism in the Middle Volga Steppes - Volume 1: The Evolution of Eurasian Pastoralism in the Bronze Age: Ecology and Demographics in the Middle Volga Region, American School of Prehistoric Research, Harvard University Press, Massachusetts.

Nicholson, S.E., 2011. Dryland Climatology. Cambridge University Press, Cambridge.

Nikolaev, M., 1997. Predvaritelniye itogi kultyrno-chronologicheskoye identifikatsii poseleniya Ai-Dai IV v Khakassii, in: Noviye Issledovaniya Archeologov Rossii i SNG., Russian Academy of Sciences and Institute for the History of Material Culture, St. Petersburg, pp. 37-39 (in Russian).

O'Connell, T.C., Levine, M.A., Hedges, R.E.M., 2003. The importance of fish in the diet of central Eurasian peoples from the Mesolithic to the Early Iron Age, in: Levine, M.A., Renfrew, C., Boyle, K. (Eds.), Prehistoric Steppe Adaptation and the Horse, McDonald Institute for Archaeological Research, Cambridge, pp. 253-268.

O’Leary, M.H., 1988. Carbon isotopes in photosynthesis. BioSci. 38, 325-336.

Okladnikov, A.P., 1959. Ancient Populations of Siberia and its Cultures. Peabody Museum, Cambridge, Massachusetts.

Pechenkina, E.A., Ambrose, S.H., Xiaolin, M., Benfer, R.A.J., 2005. Reconstructing northern Chinese Neolithic subsistence practices by isotopic analysis. J. Archaeol. Sci. 32, 1176-1189.

Pechenkina, E.A., Benfer, R.A., Zhijun, W., 2002. Diet and health changes with the intensification of millet agriculture at the end of the Chinese Neolithic: the Yangshao/Longshan transition in Shaanxi Province. Am. J. Phys. Anthropol. 117, 15-36.

Pedersen, P.O., 1947. Dental investigations of Greenland Eskimos. Proc. R. Soc. Med. 40, 726-732.

Phillips, D.L., Gregg, J.W., 2003. Source partitioning using stable isotopes: coping with too many sources. Oecologia 136, 261-269.

Pollard, A.M., 1998. Archaeological reconstruction using stable isotopes, in: Griffiths, H. (Ed.), Stable Isotopes: Integration of Biological, Ecological and Geochemical Processes, BIOS Scientific Publishers, Oxford.

Privat, K., 2004. Palaeoeconomy of the Eurasian steppe: Biomolecular Studies. Unpublished DPhil thesis, University of Oxford, Oxford. 
Privat, K.L., Schneewei $\beta$, J., Benecke, N., Vasil'ev, S.K., O’Connell, T.C., Hedges, R.E.M., Craig, 0., 2005. Economy and diet at the Late Bronze Age - Iron Age site of Čiča: Artefactual, archaeozoological \& biochemical analyses. Eurasia Antiqua 11, 419-448.

Pshenitsyna, M.H., 1997. Noviye pamyatniki rannetagarskoye epokhi na yuge Khakasii, in: Noviye Issledovaniya Archeologov Rossii i SNG, Russian Academy of Sciences and Institute for the History of Material Culture, St. Petersburg, pp. 33-37 (in Russian).

Regöly-Mérei, G., 1967. Palaeopathological examination of the skeletal finds of Naima Tolgoy and Hana. A. Arch. Acad. Sci. Hung. 19, 391-409.

Roberts, C., Cox, M., 2003. Health and Disease in Britain: From Prehistory to the Present Day. Sutton, Stroud.

Robinson, D., 2001. $\delta^{15} \mathrm{~N}$ as an integrator of the nitrogen cycle. Trends Ecol. Evol. 16, 153162.

Rugg-Gunn, A.J., 1993. Nutrition and Health. Oxford University Press, Oxford.

Salzman, P.C., 2002. Pastoral nomads: some general observations based on research in Iran. J. Anthropol. Res. 58, 245-264.

Schurr, M.R., Schoeninger, M.J., 1995. Associations between agricultural intensification and social complexity: An example from the prehistoric Ohio Valley. J. Anthrop. Arch. 14, 315339.

Schwarcz, H.P., Dupras, T.L., Fargrieve, S.I., $1999 .{ }^{15} \mathrm{~N}$ enrichment in the Sahara: in search of a global relationship. J. Archaeol. Sci. 26, 651-659.

Schwarcz, H.P., White, C.D., 2004. The grasshopper or the ant?: cultigen-use strategies in ancient Nubia from C-13 analyses of human hair. J. Archaeol. Sci. 31, 753-762.

Shishlina, N.I., Van der Plicht, J., Hedges, R.E.M., Zazovskaya, E.P., Sevastyanov, V.S., Chichagova, O.A., 2007. The Catacomb cultures of the north-west Caspian steppe: $14 \mathrm{C}$ chronology, reservoir effect, and paleodiet. Radiocarb. 49, 713-726.

Stebaeva, S., 2003. Collembolan communities of the Ubsu-Nur Basin and adjacent mountains (Russia, Tuva). Pedobiol. 47, 341-356.

Svyatko, S.V., Mallory, J.P., Murphy, E.M., Polyakov, A.V., Reimer, P.J., Schulting, R.J., 2009. New radiocarbon dates and a review of the chronology of prehistoric populations from the Minusinsk Basin, southern Siberia, Russia. Radiocarb. 51, 243-273.

Svyatko, S.V., Schulting, R.J., Mallory, J.P., Murphy, E.M., Reimer, P.J., Khartanovich, V.I., Chistov, Y.K., Sablin, M.V. submitted. Stable isotope dietary analysis of Bronze Age and Early Iron Age populations from the Minusinsk Basin, southern Siberia, Russia.

Tieszen, L.L., 1991. Natural variations in the carbon isotope values of plants: implications for archaeology, ecology, and paleoecology. J. Archaeol. Sci. 18, 261-275. 
Turner, C. G. II, 1979. Dental anthropological indications among the Jomon people of central Japan: X. Peopling of the Pacific. Am. J. Phys. Anthropol. 51, 619-636.

Vadetskaya, E.B. 1986. Arkheologicheskiye pamyatniki v Stepyakh Srednego Yeniseya. Nauka, Leningrad (in Russian).

Vainshtein, S., 1980. Nomads of South Siberia: The Pastoral Economies of Tuva. Cambridge University Press, Cambridge.

van der Plicht, J., 2004. Radiocarbon, the calibration curve and Scythian chronology, in: Scott, E.M., Alekseev, A., Zaitseva, G. (Eds.), Impact of the Environment on Human Migration in Eurasia, Kluwer Academic, Dordrecht, pp. 45-61.

van Geel, B., Bokovenko, N.A., Burova, N.D., Chugunov, K.V., Dergachev, V.A., Dirksen, V.G., Kulkova, M., Nagler, A., Parzinger, H., Van der Plicht, J., Vasiliev, S.S., Zaitseva, G.I., 2004. Climate change and the expansion of the Scythian culture after 850 BC: a hypothesis. J. Archaeol. Sci. 31, 1735-1742.

Van Klinken, G.J., 1999. Bone collagen quality indicators for palaeodietary and radiocarbon measurements. J. Archaeol. Sci. 26, 687-695.

Vogel, J.C., van der Merwe, N.J., 1977. Isotopic evidence for early maize cultivation in New York State. Am. Antiq. 42, 238-242.

Wang, R.Z., 2003. Photosynthetic pathway and morphological functional types in the steppe vegetation from Inner Mongolia, North China. Photosynthetica 41, 143-150.

Yablonsky, L.T., 2000. 'Scythian Triad' and 'Scythian World', in: Davis-Kimball, J., Murphy, E.M., Koryakova, L., Yablonsky, L.T. (Eds.), Kurgans, Ritual Sites, and Settlements Eurasian Bronze and Iron Age, BAR International Series 890, Archaeopress, Oxford, pp. 3-8.

Zaitseva, G.I., van Geel, B., Bokovenko, N.A., Chugunov, K.V., Dergachev, V.A., Dirksen, V.G., Koulkova, M.A., Nagler, A., Parzinger, G., van der Plicht, J., Bourova, N.D. and Lebedeva, L.M., 2004. Chronology and possible links between climatic and cultural change during the first millennium BC in southern Siberia and Central Asia. Radiocarb. 46, 259-276.

Zavitukhina, M.P., 1978. The Tagar Culture, in: Frozen Tombs: The Culture and Art of the Ancient Tribes of Siberia, British Museum Publications, London, pp. 79-93. 


\begin{tabular}{|c|c|c|c|c|c|c|c|c|}
\hline \multirow{3}{*}{$\frac{\text { Aymyrlyg }}{\text { Age (years) }}$} & \multicolumn{4}{|c|}{$\mathrm{n}=342$ individuals } & \multicolumn{4}{|c|}{$\mathrm{n}=44$ individuals } \\
\hline & \multicolumn{2}{|c|}{$\mathbf{N}$ individuals } & \multicolumn{2}{|c|}{$\mathrm{N}$ teeth/N sockets } & \multicolumn{2}{|c|}{$\mathrm{N}$ individuals } & \multicolumn{2}{|c|}{$\mathrm{N}$ teeth/N sockets } \\
\hline & Males & Females & Males & Females & Males & Females & Males & Females \\
\hline $18-35$ & 108 & 107 & $1441 / 2884$ & $1290 / 2694$ & 9 & 12 & $118 / 204$ & $134 / 287$ \\
\hline $36-50$ & 57 & $39 *$ & $671 / 1507$ & $369 / 1044$ & 13 & 7 & $252 / 351$ & $76 / 138$ \\
\hline $50+$ & $16^{*}$ & $15^{*}$ & $142 / 433$ & $82 / 398$ & 2 & 1 & $34 / 60$ & $11 / 25$ \\
\hline Total & 181 & 161 & $2254 / 4824$ & $1741 / 4136$ & 24 & 20 & $404 / 615$ & $221 / 450$ \\
\hline
\end{tabular}




\begin{tabular}{|c|c|c|c|}
\hline Age (yrs) & Males & Females & Total \\
\hline \multicolumn{4}{|l|}{ Dental caries } \\
\hline $18-35$ & $33.3(36 / 108)$ & $38.3(41 / 107)$ & $35.8(77 / 215)$ \\
\hline $36-50$ & $47.4(27 / 57)$ & $48.6(18 / 37)$ & $47.9(45 / 94)$ \\
\hline $50+$ & $40(6 / 15)$ & $42.9(6 / 14)$ & $41.4(12 / 29)$ \\
\hline Total & $38.3(69 / 180)$ & $41.1(65 / 158)$ & $39.6(134 / 338)$ \\
\hline \multicolumn{4}{|l|}{ Abscesses } \\
\hline $18-35$ & $27.8(30 / 108)$ & $17.8(19 / 107)$ & $22.8(49 / 215)$ \\
\hline $36-50$ & $71.9(41 / 57)$ & $74.4(29 / 39)$ & $72.9(70 / 96)$ \\
\hline $50+$ & $87.5(14 / 16)$ & $60(9 / 15)$ & $74.2(23 / 31)$ \\
\hline Total & $47(85 / 181)$ & $35.4(57 / 161)$ & $41.5(142 / 342)$ \\
\hline \multicolumn{4}{|l|}{$A M T L$} \\
\hline $18-35$ & $28.7(31 / 108)$ & $18.7(20 / 107)$ & $23.7(51 / 215)$ \\
\hline $36-50$ & $64.9(37 / 57)$ & $71.8(28 / 39)$ & $67.7(65 / 96)$ \\
\hline $50+$ & $100(16 / 16)$ & $100(15 / 15)$ & $100(31 / 31)$ \\
\hline Total & $46.4(84 / 181)$ & $39.1(63 / 161)$ & $43(147 / 342)$ \\
\hline \multicolumn{4}{|l|}{ Periodontal disease } \\
\hline $18-35$ & $67.6(73 / 108)$ & $51.4(55 / 107)$ & $59.5(128 / 215)$ \\
\hline $36-50$ & $96.5(55 / 57)$ & $100(37 / 37)$ & $97.9(92 / 94)$ \\
\hline $50+$ & $100(15 / 15)$ & $92.9(13 / 14)$ & $96.6(28 / 29)$ \\
\hline Total & $79.4(143 / 180)$ & $66.4(105 / 158)$ & $73.4(248 / 338)$ \\
\hline \multicolumn{4}{|l|}{ Calculus } \\
\hline $18-35$ & $97.2(105 / 108)$ & $95.3(102 / 107)$ & $96.3(207 / 215)$ \\
\hline $36-50$ & $94.4(51 / 57)$ & $91.9(34 / 37)$ & $90.4(85 / 94)$ \\
\hline $50+$ & $86.7(13 / 15)$ & $78.6(11 / 14)$ & $82.8(24 / 29)$ \\
\hline Total & $93.9(169 / 180)$ & $93(147 / 158)$ & $93.5(316 / 338)$ \\
\hline \multicolumn{4}{|l|}{ Extensive attrition } \\
\hline $18-35$ & $21.3(23 / 108)$ & $14(15 / 107)$ & $17.7(38 / 215)$ \\
\hline $36-50$ & $78.9(45 / 57)$ & $67.6(25 / 37)$ & $74.5(70 / 94)$ \\
\hline $50+$ & $86.7(13 / 15)$ & $78.6(11 / 14)$ & $82.8(24 / 29)$ \\
\hline Total & $45(81 / 180)$ & $32.3(51 / 158)$ & $39.1(132 / 338)$ \\
\hline
\end{tabular}




\begin{tabular}{|c|c|c|c|}
\hline Age (yrs) & Males & Females & Total \\
\hline \multicolumn{4}{|l|}{ Dental caries } \\
\hline $18-35$ & $4.4(63 / 1441)$ & $6.2(80 / 1290)$ & $5.2(143 / 2731)$ \\
\hline $36-50$ & $7.7(52 / 671)$ & $10.8(40 / 369)$ & $8.8(92 / 1040)$ \\
\hline $50+$ & $6.3(9 / 142)$ & $17.1(14 / 82)$ & $10.3(23 / 224)$ \\
\hline Total & $5.5(124 / 2254)$ & $7.7(134 / 1741)$ & $6.4(258 / 3995)$ \\
\hline \multicolumn{4}{|l|}{ Abscesses } \\
\hline $18-35$ & $86 / 2884$ & $37 / 2694$ & $123 / 5578$ \\
\hline $36-50$ & $8.2(123 / 1507)$ & $8.2(86 / 1044)$ & $8.2(209 / 2551)$ \\
\hline $50+$ & $12(52 / 433)$ & $9.3(37 / 398)$ & $10.7(89 / 831)$ \\
\hline Total & $5.4(261 / 4824)$ & $3.9(160 / 4136)$ & $4.7(421 / 8960)$ \\
\hline \multicolumn{4}{|l|}{$A M T L$} \\
\hline $18-35$ & $3.1(89 / 2884)$ & $2.1(57 / 2694)$ & $2.6(146 / 5578)$ \\
\hline $36-50$ & $12.1(182 / 1507)$ & $15.9(166 / 1044)$ & $13.6(348 / 2551)$ \\
\hline $50+$ & $30.9(134 / 433)$ & $43.2(172 / 398)$ & $36.8(306 / 831)$ \\
\hline Total & $8.4(405 / 4824)$ & $9.6(395 / 4136)$ & $8.9(800 / 8960)$ \\
\hline \multicolumn{4}{|l|}{ Calculus } \\
\hline $18-35$ & $81.1(1169 / 1441)$ & $70.9(915 / 1290)$ & $76.3(2084 / 2731)$ \\
\hline $36-50$ & $89(597 / 671)$ & 73.7 (272/369) & $83.6(869 / 1040)$ \\
\hline $50+$ & $62.7(89 / 142)$ & $53.7(44 / 82)$ & $59.4(133 / 224)$ \\
\hline Total & $82.3(1855 / 2254)$ & $70.7(1231 / 1741)$ & $77.2(3086 / 3995)$ \\
\hline \multicolumn{4}{|c|}{ Extensive attrition } \\
\hline $18-35$ & $3.5(51 / 1441)$ & $3(39 / 1290)$ & $3.3(90 / 2731)$ \\
\hline $36-50$ & $32.9(221 / 671)$ & $23.8(88 / 369)$ & $29.7(309 / 1040)$ \\
\hline $50+$ & $69.7(99 / 142)$ & $64.6(53 / 82)$ & $67.9(152 / 224)$ \\
\hline Total & $16.5(371 / 2254)$ & $10.3(180 / 1741)$ & $13.8(551 / 3995)$ \\
\hline
\end{tabular}




\begin{tabular}{|c|c|c|c|}
\hline Age (yrs) & Males & Females & Total \\
\hline \multicolumn{4}{|l|}{ Dental caries } \\
\hline $18-35$ & $11.1(1 / 9)$ & $0 / 12$ & $4.8(1 / 21)$ \\
\hline $36-50$ & $30.8(4 / 13)$ & $0 / 7$ & $20(4 / 20)$ \\
\hline $50+$ & $50(1 / 2)$ & $0 / 1$ & $33.3(1 / 3)$ \\
\hline Total & $25(6 / 24)$ & $0 / 20$ & $13.6(6 / 44)$ \\
\hline \multicolumn{4}{|l|}{ Abscesses } \\
\hline $18-35$ & $22.2(2 / 9)$ & $8.3(1 / 12)$ & $14.3(3 / 21)$ \\
\hline $36-50$ & $69.2(9 / 13)$ & $28.6(2 / 7)$ & $55(11 / 20)$ \\
\hline $50+$ & $100(2 / 2)$ & $0 / 1$ & $66.7(2 / 3)$ \\
\hline Total & $54.2(13 / 24)$ & $15(3 / 20)$ & $36.4(16 / 44)$ \\
\hline \multicolumn{4}{|l|}{$A M T L$} \\
\hline $18-35$ & $22.2(2 / 9)$ & $33.3(4 / 12)$ & $28.6(6 / 21)$ \\
\hline $36-50$ & $46.2(6 / 13)$ & $42.9(3 / 7)$ & $45(9 / 20)$ \\
\hline $50+$ & $100(2 / 2)$ & $100(1 / 1)$ & $100(3 / 3)$ \\
\hline Total & $41.7(10 / 24)$ & $40(8 / 20)$ & $40.9(18 / 44)$ \\
\hline \multicolumn{4}{|c|}{ Periodontal disease } \\
\hline $18-35$ & $77.8(7 / 9)$ & $50(6 / 12)$ & $61.9(13 / 21)$ \\
\hline $36-50$ & $100(13 / 13)$ & $85.7(6 / 7)$ & $95(19 / 20)$ \\
\hline $50+$ & $100(2 / 2)$ & $100(1 / 1)$ & $100(3 / 3)$ \\
\hline Total & $91.7(22 / 24)$ & $65(13 / 20)$ & $79.5(35 / 44)$ \\
\hline \multicolumn{4}{|l|}{ Calculus } \\
\hline $18-35$ & $100(9 / 9)$ & $100(12 / 12)$ & $100(21 / 21)$ \\
\hline $36-50$ & $100(12 / 12)$ & $85.7(6 / 7)$ & $94.7(18 / 19)$ \\
\hline $50+$ & $100(2 / 2)$ & $100(1 / 1)$ & $100(3 / 3)$ \\
\hline Total & $100(23 / 23)$ & $95(19 / 20)$ & $97.7(42 / 43)$ \\
\hline \multicolumn{4}{|c|}{ Extensive attrition } \\
\hline $18-35$ & $22.2(2 / 9)$ & $8.3(1 / 12)$ & $14.3(3 / 21)$ \\
\hline $36-50$ & $100(13 / 13)$ & $57.1(4 / 7)$ & $85(17 / 20)$ \\
\hline $50+$ & $100(2 / 2)$ & $100(1 / 1)$ & $100(3 / 3)$ \\
\hline Total & $70.8(17 / 24)$ & $30(6 / 20)$ & $52.3(23 / 44)$ \\
\hline
\end{tabular}




\begin{tabular}{|cccc|}
\hline Age (yrs) & Males & Females & Total \\
& & & \\
\hline Dental caries & & & \\
$18-35$ & $0.8(1 / 118)$ & $0 / 134$ & $0.4(1 / 252)$ \\
$36-50$ & $3.6(9 / 252)$ & $0 / 76$ & $2.7(9 / 328)$ \\
$50+$ & $5.9(2 / 34)$ & $0 / 11$ & $4.4(2 / 45)$ \\
Total & $3(12 / 404)$ & $0 / 221$ & $1.9(12 / 625)$ \\
\hline Abscesses & & & \\
$18-35$ & $2.5(5 / 204)$ & $0.3(1 / 287)$ & $1.2(6 / 491)$ \\
$36-50$ & $4.6(16 / 351)$ & $4.3(6 / 138)$ & $4.5(22 / 489)$ \\
$50+$ & $11.7(7 / 60)$ & $0 / 25$ & $8.2(7 / 85)$ \\
Total & $4.6(28 / 615)$ & $1.6(7 / 450)$ & $3.3(35 / 1065)$ \\
\hline \multicolumn{5}{c}{} & \\
$18-35$ & $1(2 / 204)$ & $6.3(18 / 287)$ & $4.1(20 / 491)$ \\
$36-50$ & $2.8(10 / 351)$ & $8(11 / 138)$ & $4.3(21 / 489)$ \\
$50+$ & $26.7(16 / 60)$ & $44(11 / 25)$ & $31.8(27 / 85)$ \\
Total & $4.6(28 / 615)$ & $8.9(40 / 450)$ & $6.4(68 / 1065)$ \\
\hline AMTL & & & \\
$18-35$ & $88.1(104 / 118)$ & $76.1(102 / 134)$ & $81.7(206 / 252)$ \\
$36-50$ & $91.6(217 / 237)$ & $86.8(66 / 76)$ & $90.4(283 / 313)$ \\
$50+$ & $52.9(18 / 34)$ & $36.4(4 / 11)$ & $48.9(22 / 45)$ \\
Total & $87.1(339 / 389)$ & $77.8(172 / 221)$ & $83.8(511 / 610)$ \\
\hline Calculus & & \\
$18-35$ & $3.4(4 / 118)$ & $2.2(3 / 134)$ & $2.8(7 / 252)$ \\
$36-50$ & $29.8(75 / 252)$ & $38.2(29 / 76)$ & $31.7(104 / 328)$ \\
$50+$ & $70.6(24 / 34)$ & $100(11 / 11)$ & $77.8(35 / 45)$ \\
Total & $25.5(103 / 404)$ & $19.5(43 / 221)$ & $23.4(146 / 625)$ \\
\hline
\end{tabular}




\begin{tabular}{|c|c|c|c|c|c|c|c|}
\hline Context & Sex & Age & $\begin{array}{c}\text { Bone } \\
\text { sampled }\end{array}$ & $\delta^{13} \mathrm{C}$ & & $\begin{array}{l}\text { ollagen } \\
\text { yield \% }\end{array}$ & C:N \\
\hline \multicolumn{8}{|l|}{$A i-D a i$} \\
\hline K4 M3 Sk 2 & $\mathrm{~F}$ & $12-17$ & occipital & -14.7 & 10.2 & 2.5 & 3.4 \\
\hline K5 M1 Sk 3 & $\mathrm{~F}$ & $12-17$ & parietal & -15.3 & 10.6 & 1.9 & 3.7 \\
\hline K2 M1 Sk 4 & $\mathrm{~F}$ & $18-35$ & frontal & -15.0 & 11.8 & 2.4 & 3.3 \\
\hline K3 M1 Sk R & $\mathrm{F}$ & $18-35$ & occipital & -13.8 & 11.5 & 1.7 & 3.6 \\
\hline K4 M3 Sk 4 & $\mathrm{~F}$ & $18-35$ & temporal & -12.8 & 9.9 & 2.0 & 3.6 \\
\hline K4 M3 Sk 5 & $\mathrm{~F}$ & $18-35$ & occipital & -14.2 & 10.4 & 2.0 & 3.4 \\
\hline K8 M2A Sk 1 & $\mathrm{~F}$ & $18-35$ & rib & -16.2 & 10.2 & 1.9 & 3.3 \\
\hline K8 M2A Sk 2 & F & $36-50$ & rib & -16.1 & 10.3 & 1.8 & 3.6 \\
\hline K8 M2A Sk 3 & $\mathrm{~F}$ & $36-50$ & rib & -16.6 & 10.6 & 2.1 & 3.6 \\
\hline K4 Sk1 & M & $18-35$ & occipital & -15.2 & 11.2 & 3.0 & 3.4 \\
\hline K1 M1 Sk1 & M & $36-50$ & parietal & -14.4 & 10.2 & 3.0 & 3.4 \\
\hline K3 M1 Sk2 & M & $36-50$ & parietal & -15.2 & 11.0 & 1.8 & 3.3 \\
\hline K3 M2 Sk4 & M & $36-50$ & temporal & -14.6 & 10.2 & 2.1 & 3.3 \\
\hline K4 M3 Sk7 & M & $36-50$ & parietal & -15.6 & 10.2 & 1.7 & 3.3 \\
\hline K5 M1 Sk8 & M & $36-50$ & parietal & -15.5 & 10.8 & 2.0 & 3.6 \\
\hline K6 M2 Sk2 & M & $36-50$ & parietal & -16.6 & 11.2 & 2.4 & 3.4 \\
\hline K8 M2B Sk1 & M & $36-50$ & rib & -15.3 & 10.4 & 1.9 & 3.4 \\
\hline K8 M2B Sk2 & M & $50+$ & rib & -15.3 & 11.0 & 4.5 & 3.5 \\
\hline \multicolumn{8}{|l|}{ Aymyrlyg } \\
\hline D. 7. Sk1(i) & $\mathrm{F}$ & $36-50$ & rib & -14.2 & 13.0 & 3.5 & 3.4 \\
\hline VII. 8. Sk1 & $\mathrm{F}$ & $36-50$ & rib & -15.3 & 14.0 & 6.9 & 3.3 \\
\hline VIII. 17. Sk2 & $\mathrm{F}$ & $36-60$ & rib & -15.7 & 13.8 & 5.8 & 3.3 \\
\hline VIII. 54. Sk5 & $\mathrm{F}$ & $36-50$ & rib & -13.6 & 13.0 & 3.1 & 3.6 \\
\hline XX. 7. Sk1 & $\mathrm{F}$ & $18-35$ & rib & -13.9 & 12.3 & 2.1 & 3.3 \\
\hline XX. 7. Sk5 & $\mathrm{F}$ & $18-35$ & rib & -13.2 & 11.8 & 7.8 & 3.4 \\
\hline XX. 9. Sk4 & $\mathrm{F}$ & $18-35$ & rib & -17.2 & 14.0 & 4.0 & 3.4 \\
\hline ??XXIII & $\mathrm{F}$ & $18-35$ & rib & -16.2 & 13.2 & 5.0 & 3.4 \\
\hline XXIII. 8 & $\mathrm{~F}$ & $50+$ & rib & -15.0 & 13.2 & 6.8 & 3.4 \\
\hline VI. 16. Sk4 & M & $18-35$ & rib & -15.2 & 12.8 & 1.0 & 3.3 \\
\hline XX. 7. Sk2 & M & $18-35$ & rib & -13.9 & 12.9 & 3.6 & 3.5 \\
\hline XX. 10. Sk2 & M & $18-35$ & rib & -16.2 & 13.9 & 4.4 & 3.6 \\
\hline XX. 10. Sk4 & M & $18-35$ & rib & -16.8 & 13.6 & 1.9 & 3.6 \\
\hline XXI. 4. Sk4 & M & $18-35$ & rib & -14.1 & 13.0 & 6.1 & 3.5 \\
\hline XXIII. 4 & M & $18-35$ & rib & -17.5 & 13.8 & 6.2 & 3.6 \\
\hline XXIII. 11.Sk1 & M & $18-35$ & rib & -14.9 & 13.1 & 3.0 & 3.5 \\
\hline XXIII. 11. Sk3 & M & $18-35$ & rib & -17.2 & 12.9 & 2.5 & 3.6 \\
\hline XXV. 16. Sk1 & M & $18-35$ & rib & -15.1 & 13.1 & 1.4 & 3.6 \\
\hline VIII. 17. Sk1 & M & $36-50$ & rib & -14.7 & 13.5 & 3.6 & 3.6 \\
\hline XX. 8. Sk2 & M & $50+$ & rib & -15.5 & 13.3 & 5.9 & 3.4 \\
\hline No context & M & $50+$ & rib & -16.1 & 13.4 & 4.4 & 3.4 \\
\hline
\end{tabular}




\begin{tabular}{rccccc} 
& $\boldsymbol{\delta}^{\mathbf{1 3}} \mathbf{C}$ & $\underline{ \pm}$ & $\boldsymbol{\delta}^{\mathbf{1 5}} \mathbf{N}$ & $\mathbf{\pm}$ & $\mathbf{n}$ \\
\hline Ai-Dai & & & & & \\
Average $=$ & -15.1 & 0.97 & 10.6 & 0.52 & 18 \\
F average $=$ & -15.0 & 1.25 & 10.6 & 0.62 & 9 \\
M average $=$ & -15.3 & 0.63 & 10.7 & 0.44 & 9 \\
Aymyrlyg & & & & & \\
Average $=$ & -15.3 & 1.25 & 13.2 & 0.55 & 21 \\
F average $=$ & -14.9 & 1.32 & 13.1 & 0.75 & 9 \\
M average $=$ & -15.6 & 1.17 & 13.3 & 0.37 & 12
\end{tabular}




\begin{tabular}{|c|c|c|c|c|c|}
\hline Context & Species & $\delta^{13} \mathrm{C}$ & $\delta^{15} \mathbf{N}$ & coll yield & $C: N$ \\
\hline Ai-Dai IV, Trench 1 & $\operatorname{dog}$ & -15.7 & 9.3 & 1.9 & 3.6 \\
\hline Ai-Dai II K4 M2 & cattle & -20.8 & 6.3 & 2 & 3.6 \\
\hline Aymyrlyg M35 & horse & -20.9 & 7.2 & 1 & 3.6 \\
\hline Aymyrlyg XXXI M139 & sheep/goat & -19.1 & 7.1 & 1.9 & 3.5 \\
\hline Aymyrlyg II K13 & sheep/goat & -19.0 & 9.4 & 1.1 & 3.5 \\
\hline Ai-Dai IV, Trench 1 & roe deer & - & - & failed & \\
\hline & ore average & -20.0 & 7.5 & $(n=4)$ & \\
\hline
\end{tabular}




\begin{tabular}{ccc|ccc}
\multicolumn{5}{|c|}{$\boldsymbol{\delta}^{\mathbf{1 3}} \mathbf{C}$} & $\boldsymbol{\delta}^{\mathbf{1 5}} \mathbf{N}$ \\
Kurgan & $\mathbf{X}$ & $\mathbf{\pm}$ & $\mathbf{X}$ & $\mathbf{\pm}$ & $\mathbf{n}$ \\
\hline K1 & -14.4 & - & 10.2 & - & 1 \\
K2 & -15.0 & - & 11.8 & - & 1 \\
K3 & -14.5 & 0.73 & 10.9 & 0.63 & 3 \\
K4 & -14.5 & 1.08 & 10.4 & 0.49 & 5 \\
K5 & -15.4 & 0.14 & 10.7 & 0.14 & 2 \\
K6 & -16.6 & - & 11.2 & - & 1 \\
K8 & -15.9 & 0.58 & 10.5 & 0.32 & 5
\end{tabular}




\begin{tabular}{|c|c|c|c|c|c|c|c|c|}
\hline Context & Sex & Age & $\delta^{13} \mathrm{C}$ & $\delta^{15} \mathrm{~N}$ & $\begin{array}{c}\text { Collagen } \\
\text { yield \% }\end{array}$ & C:N & Caries & Calculus \\
\hline \multicolumn{9}{|l|}{$\overline{A i-D a i}$} \\
\hline K4 M3 Sk 2 & $\mathrm{~F}$ & $12-17$ & -14.7 & 10.2 & 2.5 & 3.4 & juvenile, excluded & \\
\hline K5 M1 Sk 3 & $\mathrm{~F}$ & $12-17$ & -15.3 & 10.6 & 1.9 & 3.7 & juvenile, excluded & \\
\hline K2 M1 Sk 4 & $\mathrm{~F}$ & $18-35$ & -15.0 & 11.8 & 2.4 & 3.3 & $0 / 7$ & none \\
\hline K3 M1 Sk R & $\mathrm{F}$ & $18-35$ & -13.8 & 11.5 & 1.7 & 3.6 & $0 / 12$ & slight \\
\hline K4 M3 Sk 4 & $\mathrm{~F}$ & $18-35$ & -12.8 & 9.9 & 2.0 & 3.6 & $0 / 17$ & slight \\
\hline K4 M3 Sk 5 & $\mathrm{~F}$ & $18-35$ & -14.2 & 10.4 & 2.0 & 3.4 & $0 / 27$ & slight \\
\hline K8 M2A Sk 1 & $\mathrm{~F}$ & $18-35$ & -16.2 & 10.2 & 1.9 & 3.3 & $0 / 9$ & slight \\
\hline K8 M2A Sk 2 & $\mathrm{~F}$ & $36-50$ & -16.1 & 10.3 & 1.8 & 3.6 & $0 / 23$ & slight \\
\hline K8 M2A Sk 3 & $\mathrm{~F}$ & $36-50$ & -16.6 & 10.6 & 2.1 & 3.6 & $0 / 22$ & medium \\
\hline K4 Sk1 & M & $18-35$ & -15.2 & 11.2 & 3.0 & 3.4 & $0 / 19$ & slight \\
\hline K1 M1 Sk1 & M & $36-50$ & -14.4 & 10.2 & 3.0 & 3.4 & $1 / 25$ & slight \\
\hline K3 M1 Sk2 & M & $36-50$ & -15.2 & 11.0 & 1.8 & 3.3 & $0 / 10$ & slight \\
\hline K3 M2 Sk4 & M & $36-50$ & -14.6 & 10.2 & 2.1 & 3.3 & $0 / 8$ & slight \\
\hline K4 M3 Sk7 & M & $36-50$ & -15.6 & 10.2 & 1.7 & 3.3 & $6 / 15$ & unobs \\
\hline K5 M1 Sk8 & M & $36-50$ & -15.5 & 10.8 & 2.0 & 3.6 & $0 / 25$ & slight \\
\hline K6 M2 Sk2 & M & $36-50$ & -16.6 & 11.2 & 2.4 & 3.4 & $1 / 26$ & medium \\
\hline K8 M2B Sk1 & M & $36-50$ & -15.3 & 10.4 & 1.9 & 3.4 & $0 / 24$ & slight \\
\hline K8 M2B Sk2 & M & $50+$ & -15.3 & 11.0 & 4.5 & 3.5 & $0 / 15$ & slight \\
\hline \multicolumn{9}{|l|}{ Aymyrlyg } \\
\hline D. $7 . \operatorname{Sk} 1(\mathrm{i})$ & $\mathrm{F}$ & $36-50$ & -14.2 & 13.0 & 3.5 & 3.4 & unobs & unobs \\
\hline VII. 8. Sk1 & $\mathrm{F}$ & $36-50$ & -15.3 & 14.0 & 6.9 & 3.3 & unobs & unobs \\
\hline VIII. 17. Sk2 & $\mathrm{F}$ & $36-60$ & -15.7 & 13.8 & 5.8 & 3.3 & unobs & unobs \\
\hline VIII. 54. Sk5 & $\mathrm{F}$ & $36-50$ & -13.6 & 13.0 & 3.1 & 3.6 & $0 / 11$ & slight \\
\hline XX. 7. Sk1 & $\mathrm{F}$ & $18-35$ & -13.9 & 12.3 & 2.1 & 3.3 & $5 / 13$ & flecks \\
\hline XX. 7. Sk5 & $\mathrm{F}$ & $18-35$ & -13.2 & 11.8 & 7.8 & 3.4 & $5 / 22$ & flecks \\
\hline XX. 9. Sk4 & $\mathrm{F}$ & $18-35$ & -17.2 & 14.0 & 4 & 3.4 & $0 / 23$ & slight/medium \\
\hline ??XXIII & $\mathrm{F}$ & $18-35$ & -16.2 & 13.2 & 5 & 3.4 & unobs & unobs \\
\hline XXIII. 8 & $\mathrm{~F}$ & $50+$ & -15.0 & 13.2 & 6.8 & 3.4 & $1 / 18$ & unobs \\
\hline VI. 16. Sk4 & M & $18-35$ & -15.2 & 12.8 & 1 & 3.3 & $0 / 8$ & medium \\
\hline XX. 7. Sk2 & $\mathrm{M}$ & $18-35$ & -13.9 & 12.9 & 3.6 & 3.5 & unobs & unobs \\
\hline XX. 10. Sk2 & $\mathrm{M}$ & $18-35$ & -16.2 & 13.9 & 4.4 & 3.6 & $2 / 12$ & flecks \\
\hline XX. 10. Sk4 & M & $18-35$ & -16.8 & 13.6 & 1.9 & 3.6 & unobs & unobs \\
\hline XXI. 4. Sk4 & M & $18-35$ & -14.1 & 13.0 & 6.1 & 3.5 & $0 / 24$ & slight/medium \\
\hline XXIII. 4 & M & $18-35$ & -17.5 & 13.8 & 6.2 & 3.6 & $0 / 12$ & slight/medium \\
\hline XXIII. 11. Sk1 & M & $18-35$ & -14.9 & 13.1 & 3 & 3.5 & unobs & unobs \\
\hline XXIII. 11. Sk3 & M & $18-35$ & -17.2 & 12.9 & 2.5 & 3.6 & unobs & unobs \\
\hline XXV. 16. Sk1 & M & $18-35$ & -15.1 & 13.1 & 1.4 & 3.6 & $2 / 12$ & slight \\
\hline VIII. 17. Sk1 & $\mathrm{M}$ & $36-50$ & -14.7 & 13.5 & 3.6 & 3.6 & unobs & unobs \\
\hline XX. 8. Sk2 & M & $50+$ & -15.5 & 13.3 & 5.9 & 3.4 & unobs & unobs \\
\hline No context & $\mathrm{M}$ & $50+$ & -16.1 & 13.4 & 4.4 & 3.4 & unobs & unobs \\
\hline
\end{tabular}




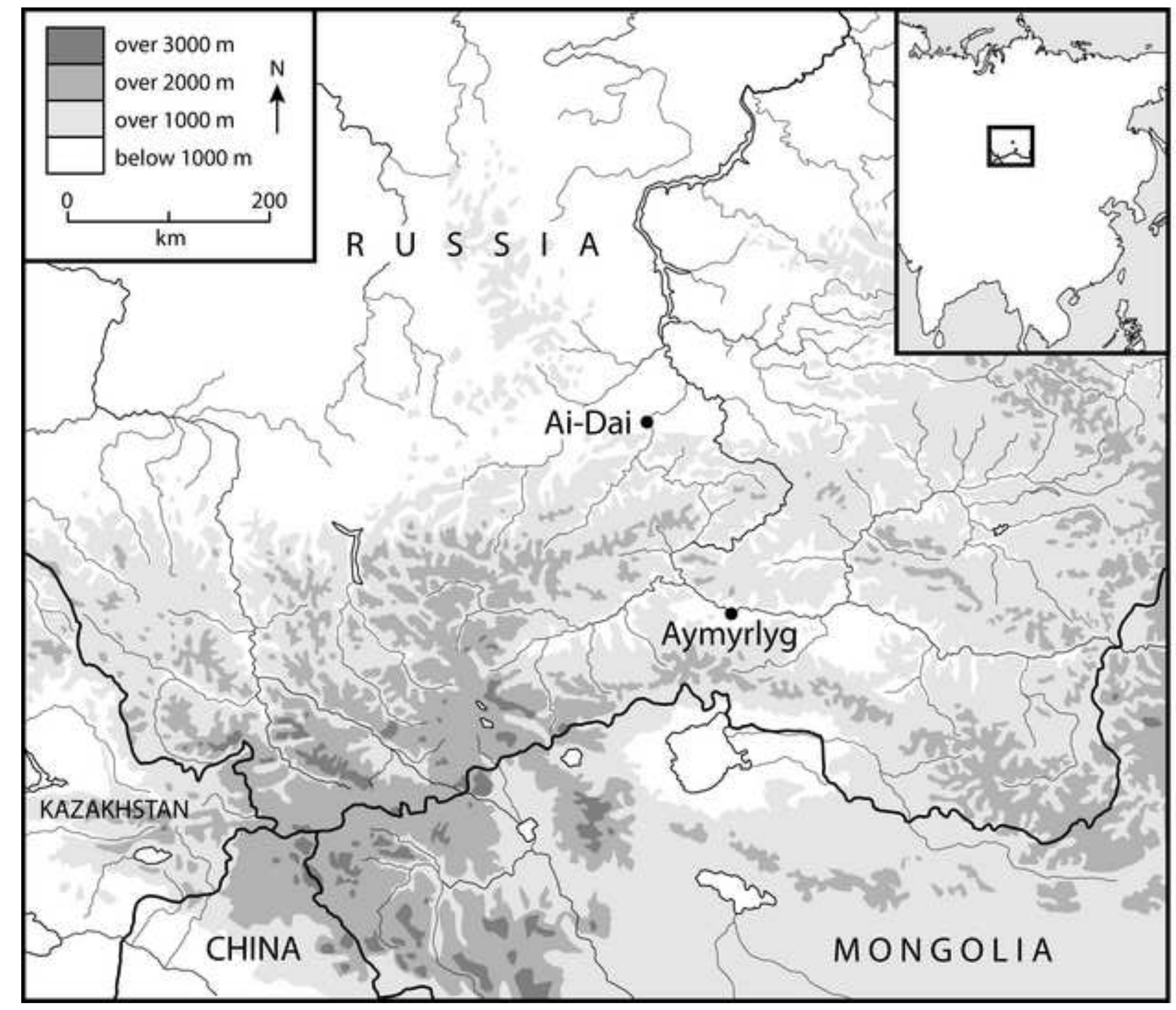




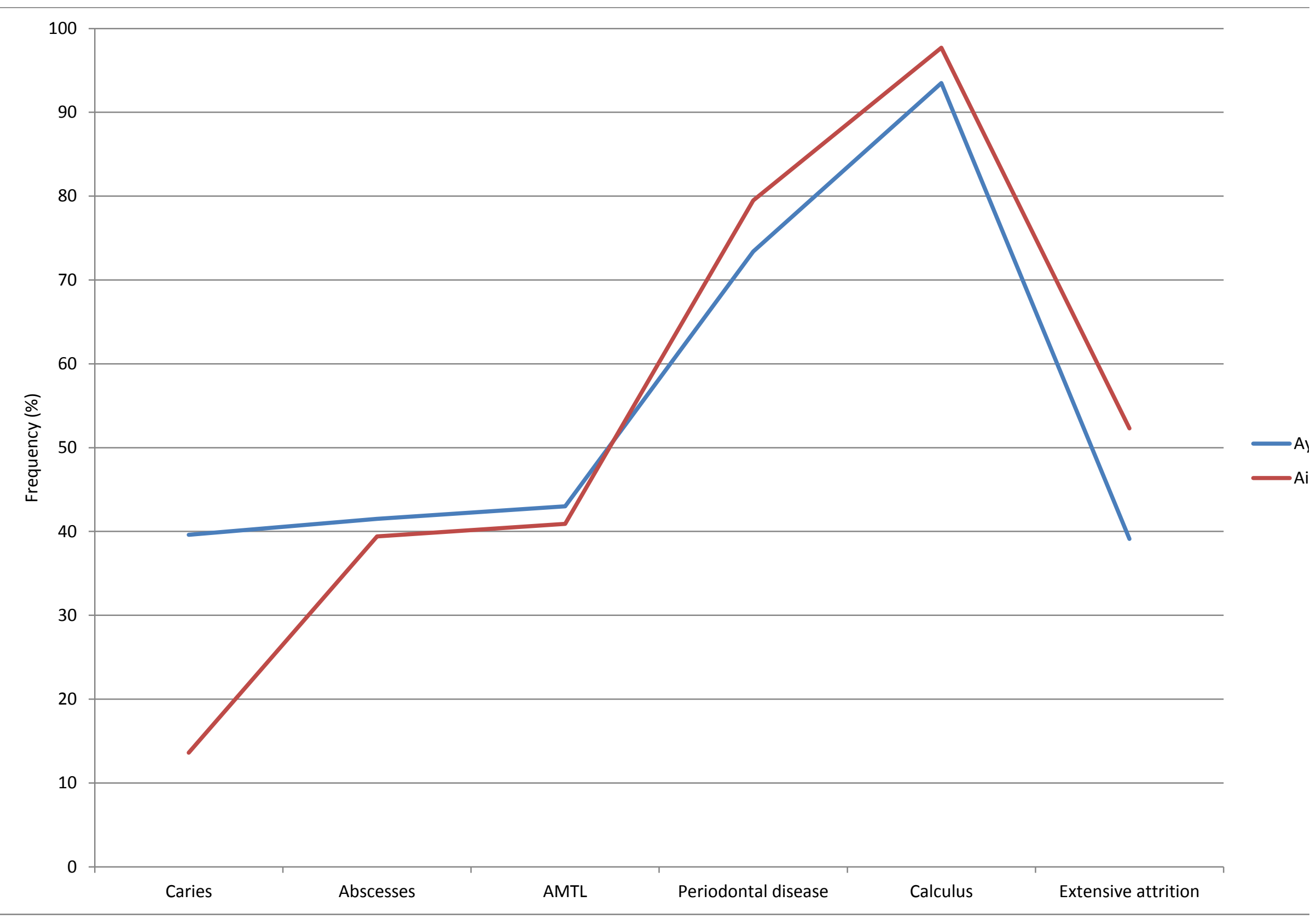


Figure

ACCEPTED MANUSCRIPT

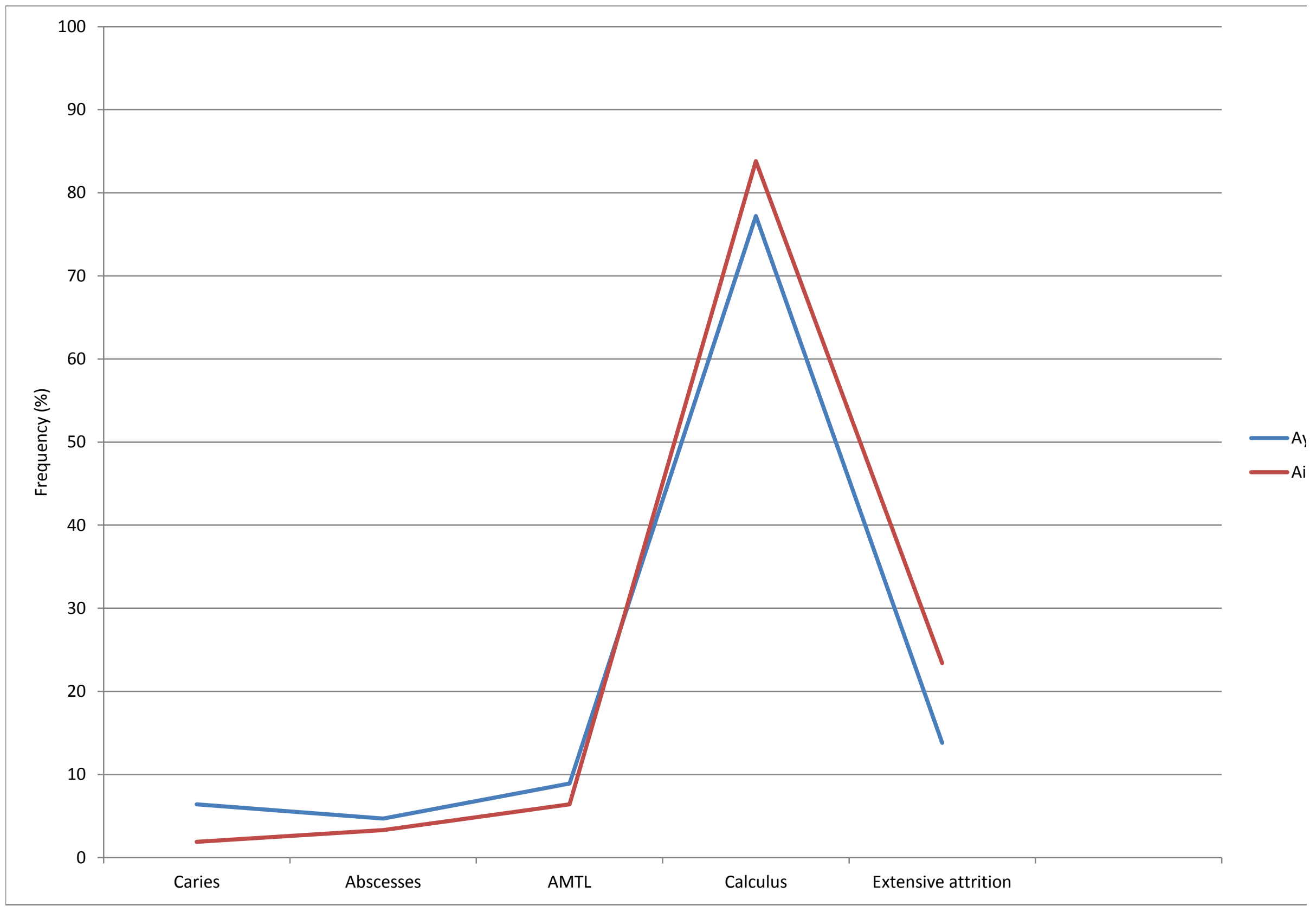




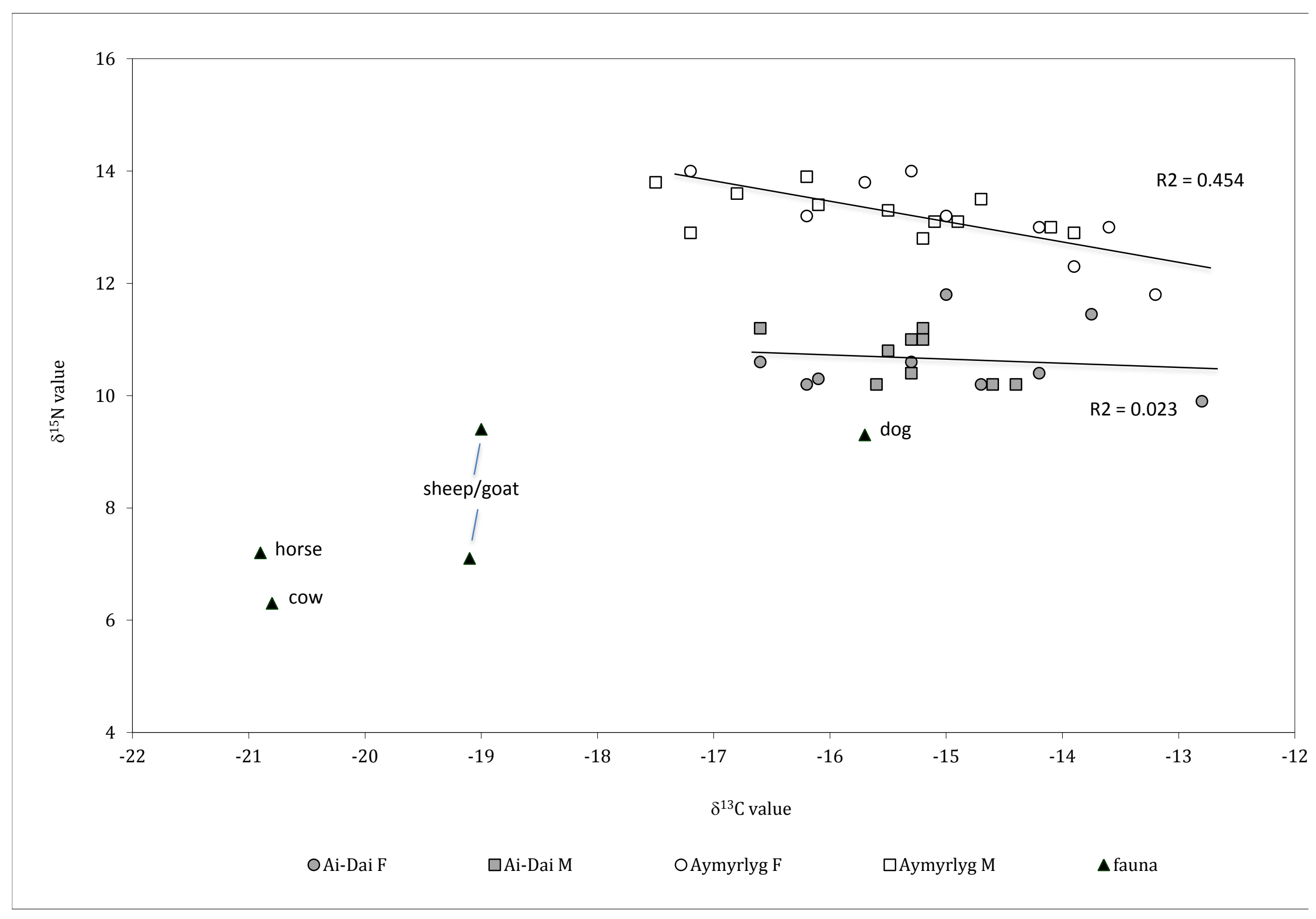

